\title{
New dinosaur sites correlated with Upper Maastrichtian pelagic deposits in the Spanish Pyrenees: implications for the dinosaur extinction pattern in Europe
}

\author{
^Nieves López-Martínez, †José Ignacio Canudo, ‡Lluís Ardèvol, \\ $\mathbb{S}, \mathbb{} \|$ Xabier Pereda Suberbiola, $\mathbb{S X a b i e r}$ Orue-Etxebarria, †Gloria Cuenca-Bescós, \\ †José Ignacio Ruiz-Omeñaca, $\mathbb{S} X a b i e r$ Murelaga and $\|$ Monique Feist \\ *Depto. Paleontología, Facultad de C.Geológicas-IGE, Universidad Complutense-CSIC, 28040 Madrid, Spain \\ †Dept. Geología, Facultad de Ciencias, Universidad de Zaragoza, 50009 Zaragoza, Spain \\ ‡GeoPlay, PO Box 12, 25620 Tremp, Lleida, Spain \\ $\$ D e p t$. Estratigrafía y Paleontología, Facultad de Ciencias, Universidad del País Vasco-Euskal Herriko Unibertsitatea, \\ Apdo. 644, 48080 Bilbao, Spain \\ \Muséum National d'Histoire Naturelle, Lab. Paléontologie, 8 rue Buffon, 75005 Paris, France \\ |Institut des Sciences de l'Évolution, Université Montpellier II, place E. Bataillon, 34095 Montpellier, France
}

Revised manuscript accepted 24 September 2000

\begin{abstract}
Six new dinosaurs sites have been found close to the Cretaceous/Tertiary boundary in Arén (south-central Pyrenees, Huesca, Spain) in coastal and non-marine deposits of the Arén and Tremp Formations. The sites contain articulated remains (skull elements, vertebrae, hind-limb bones) and isolated teeth and bones of hadrosaurids, three types of theropod teeth, one sauropod, at least seven types of eggshells (six ornithoid types and one Megaloolithidae probably from a sauropod), remains of other vertebrates, and four charophyte species. The fossil-bearing rocks have been correlated with marine sediments containing planktonic foraminifera from the uppermost Maastrichtian Abathomphalus mayaroensis Biozone. These rich and diversified dinosaur assemblages enable more accurate dating of the faunal changes that took place during the Maastrichtian in Europe and support the hypothesis of a sudden dinosaur extinction at the Cretaceous/Tertiary boundary.
\end{abstract}

KEY WorDs: Cretaceous/Tertiary boundary; Maastrichtian; marine-continental correlations; dinosaurs; charophytes; Pyrenees.

\section{Introduction}

Dinosaur remains are mostly found in non-marine rocks; therefore, their accurate age determination is often problematic. This paper presents one of the rare cases where dinosaur sites can be accurately dated, and the first to be directly correlated with the uppermost Cretaceous planktonic foraminiferal biozone. Six new dinosaur-rich sites were discovered by L. Ardèvol (GeoPlay) and F. López Olmedo (INYPSA) in uppermost Cretaceous rocks on the northern limb of the Tremp syncline near Arén (Huesca, southcentral Pyrenees, Spain; Figure 1; López-Olmedo \& Ardèvol, in press). The sites, named Blasi 1, $1 \mathrm{~b}$ and $2-5$, contain articulated and scattered dinosaur bones, teeth and eggshell fragments, together with remains of other vertebrates (bony fishes, amphibians, lepidosaurs, turtles and crocodiles); charophytes occur only at Blasi 2. The fossil-bearing rocks are located on top of the Arén Formation and in the lower part of the Tremp Formation. Downdip these dinosaur localities can be correlated with deep marine sediments containing planktonic foraminifera from the topmost Maastrichtian Abathomphalus mayaroensis Biozone, near the Cretaceous/Tertiary boundary (Figure 2).

Other European dinosaur localities in non-marine rocks previously considered to be Maastrichtian by authors (e.g. Grigorescu, 1983; Buffetaut \& Le Loeuff, 1991; Buffetaut et al., 1997; Gheerbrant et al., 1997; Laurent et al., 1999; Garcia et al., 1999), need to be recalibrated in the light of the new chronostratigraphic scale of Gradstein et al. (1995) and 
refinements in marine-continental biostratigraphic correlation (Riveline et al., 1996). The changes introduced to the duration of the stages has led to rocks previously assigned to the Early Maastrichtian (Figure 3) to be dated as Late Campanian, particularly those containing Septorella charophyte assemblages.

The dinosaur-rich Arén sites, among the youngest in the world, are crucial for establishing the pattern of the Late Cretaceous dinosaur succession and extinction in Europe. In particular, they contradict the hypothesis that dinosaur diversity decreased before their extinction, and that the extinction was earlier in Europe than in North America (Colombo, 1996; Galbrun, 1997), already challenged by LópezMartínez et al. (1998) and Casanovas et al. (1999a).

\section{Geological setting and depositional framework}

The dinosaur-bearing strata are exposed along the northern limb of an east-west-trending syncline (Tremp) in the south-central Pyrenean thrust unit (Figure 1). This belt exposes rocks that reflect sediment deposition along the axis of an elongate foredeep basin, which deepens westward to the Atlantic Ocean. The foredeep was filled with basinal turbidites and prodelta shales, followed by deltaic sandstones and fluvial red beds (Arén Sandstone and Tremp Formation, respectively; Figure 2). These deposits are $3400 \mathrm{~m}$ thick and range in age from Santonian to Maastrichtian.

The sands of the Arén Sandstone are composed of quartz with scarce feldspar, chert, quartzite, mica, and fossil debris, and show medium- and large-scale cross bedding (Nagtegaal et al., 1983). These rocks are transitionally overlain by lagoonal/marsh marls and red beds of the lower part of the Tremp Formation (Liebau, 1973; Díaz-Molina, 1987; Krauss, 1990). The Blasi 1 site is located on top of the Arén Sandstone whereas Blasi 2-5 are located within the lower part of the Tremp Formation (Figures 1, 2).

The depositional assemblages of the Upper Cretaceous foredeep have been divided into four depositional sequences (Arén 1-4) bounded by sequence boundaries H1-5 (Figure 2; Ardèvol et al., 2000). The Arén dinosaur sites occur in delta-front, lagoonal, and fluvial deposits of the Arén 4 sequence, dated as latest Maastrichtian (Figure 2). The chronostratigraphy of the sequences and dinosaur sites is discussed below (Section 6). The sites are described in ascending stratigraphic order.

\section{Dinosaur sites}

The stratigraphic location of the fossil sites is indicated in the cross-section (Figure 2), and their fossil content in Table 1 . Blasi 1 is situated on top of a 60-m-thick sandstone unit of the marine Arén Formation, which dips $30^{\circ}$ to the south. The sandstone is a mixed arenite with white, coarse, wellrounded quartz grains. Iron nodules and remnants of iron crusts are locally present. Large dinosaur bones and crocodilian teeth are scattered over an area of several hundred square metres. Most of the bones are fragmentary limb remains lacking proximal or distal ends, but there are several associated bones belonging to a hadrosaurid skull (Figures 5-7).

Blasi 2 occurs in a $6.5-\mathrm{m}$-thick interval of grey marls that overlie the sandstones of Blasi 1 (Figure 2). Nearly $5000 \mathrm{~kg}$ of sediment have been washed, resulting in the extraction of vertebrate microfossils (fish, amphibians, squamates and turtles), some dinosaur teeth (theropods, hadrosaurids, a sauropod) and eggshells (Tables 1, 2). Plant debris, charophytes and gastropods are common, but mammal remains have not been found. Blasi $1 \mathrm{~b}$ is situated $150 \mathrm{~m}$ to the east in an equivalent stratigraphic position. It has only yielded large, weathered and fragmentary dinosaur bones: three dorsal vertebrae and a few rib remains of a hadrosaurid, and limb bone fragments of an indeterminate dinosaur (Table 1).

Blasi 3 is situated in a 1 -m-thick channelized sandstone body that overlies the marls of Blasi 2 (Figure 2). The fine-grained, matrix-supported feldspathic sandstone contains Ophiomorpha burrows. The site has yielded about 70 dinosaurian bones, most of which probably belong to a single hadrosaurid individual. They were scattered over an area of about $70 \mathrm{~m}^{2}$ (Tables 1, 2). All together, 19 caudal vertebrae were present in an area $4 \mathrm{~m}^{2}$ : eight caudal vertebrae are preserved in anatomical connection, while additional caudal vertebrae and chevron bones are slightly disarticulated (Figure 4). Other hadrosaurid material consists of a maxilla fragment, poorly preserved isolated teeth, two cervical vertebrae, several distal caudal centra and chevrons, several rib remains, one ilium and two femora. Moreover, isolated teeth from a large theropod dinosaur, crocodilian bones and turtle plates have also been found (Tables 1, 2).

Blasi 4 and Blasi 5 occur $3 \mathrm{~km}$ to the west, $70 \mathrm{~m}$ and $100 \mathrm{~m}$ respectively above Blasi 3 (Figure 2). Blasi 4 is on top of a $0.5-\mathrm{m}$-thick, channelized, microconglomerate bed. It contains a few fragments of hadrosaurid bones, mainly vertebrae, as well as crocodilian and turtle remains and internal casts of bivalves. Blasi 5 is in a grey mudstone intercalation within shaly red beds; it has yielded turtle plates, crocodilian osteoderms and several fragments of vertebrae and long bones apparently belonging to hadrosaurs (Table 1). 


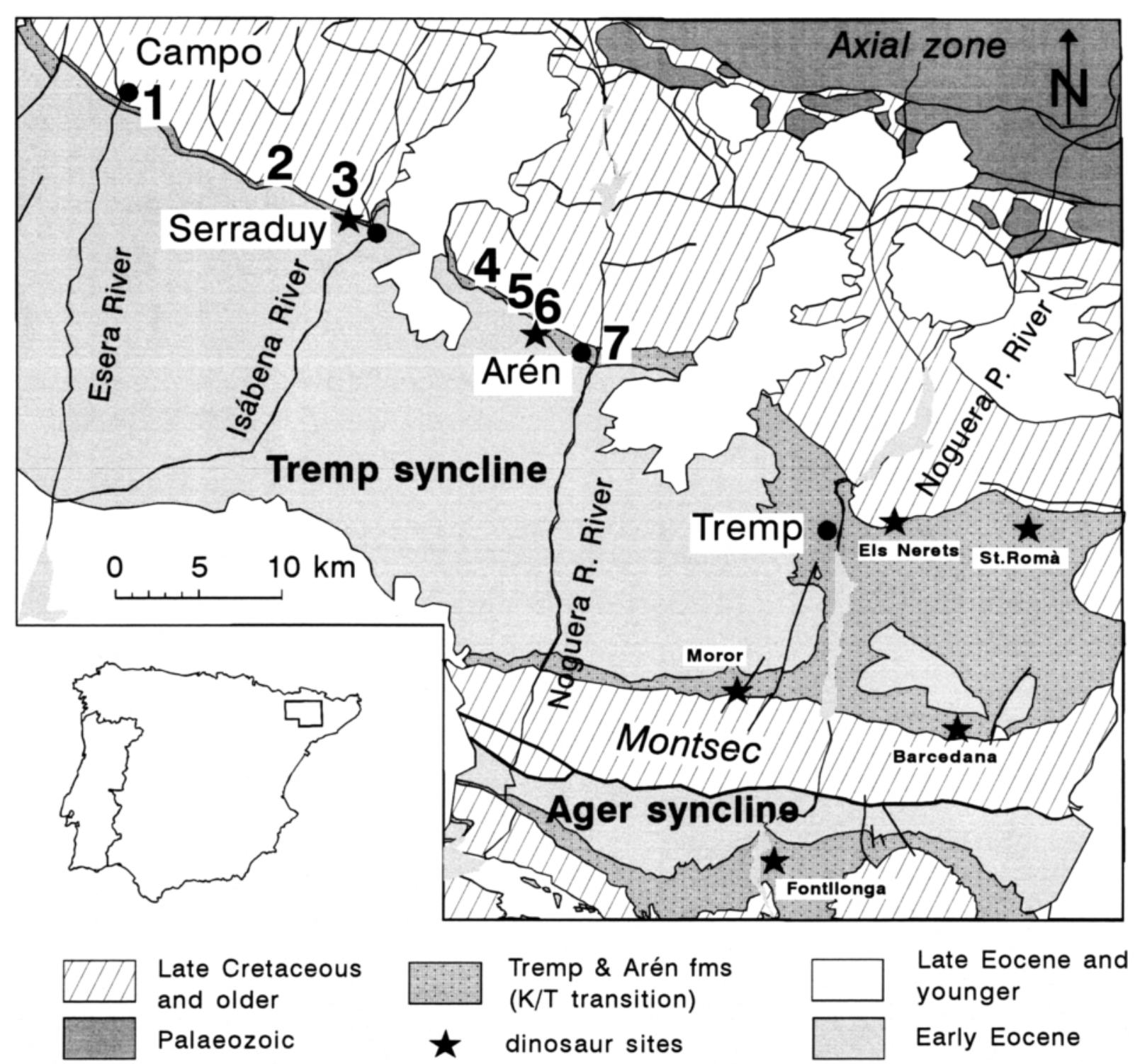

Figure 1. Simplified geologic map of the Tremp and Ager synclines (south-central Pyrenees, Spain). Numbers refer to the stratigraphic sections in Figure 2.

The vertebrate fossils from Arén are mostly fragmentary with a high proportion of splinters, with the notable exceptions of the associated remains from Blasi 1 and 3 and the articulated remains from Blasi 3, which indicate an absence of reworking processes and rapid burial probably after necrokinesis. Conversely, the microconglomeratic matrix of the Blasi 4 site covers the fracture surfaces of the bones, suggesting resedimentation and transport prior to final burial.

\section{The dinosaurs}

We have recognized at least eight dinosaur taxa: one type of hadrosaur on the basis of bones and teeth, a sauropod (one tooth and one Megaloolithidae eggshell-type), three types of theropod teeth and six 'ornithoid' eggshell-types from theropod dinosaurs and birds. The fossil material from the Arén sites is housed in the Museo Paleontológico of the Universidad de Zaragoza, Spain (MPZ).

\subsection{Hadrosaurid ornithopods}

Blasi 1 hadrosaurid. Hadrosaurid skull bones and a lower jaw with teeth have been recovered from Blasi 1. The material, which probably belongs to a single individual, consists of a left jugal, a fragmentary left maxilla with teeth, a left dentary preserving 


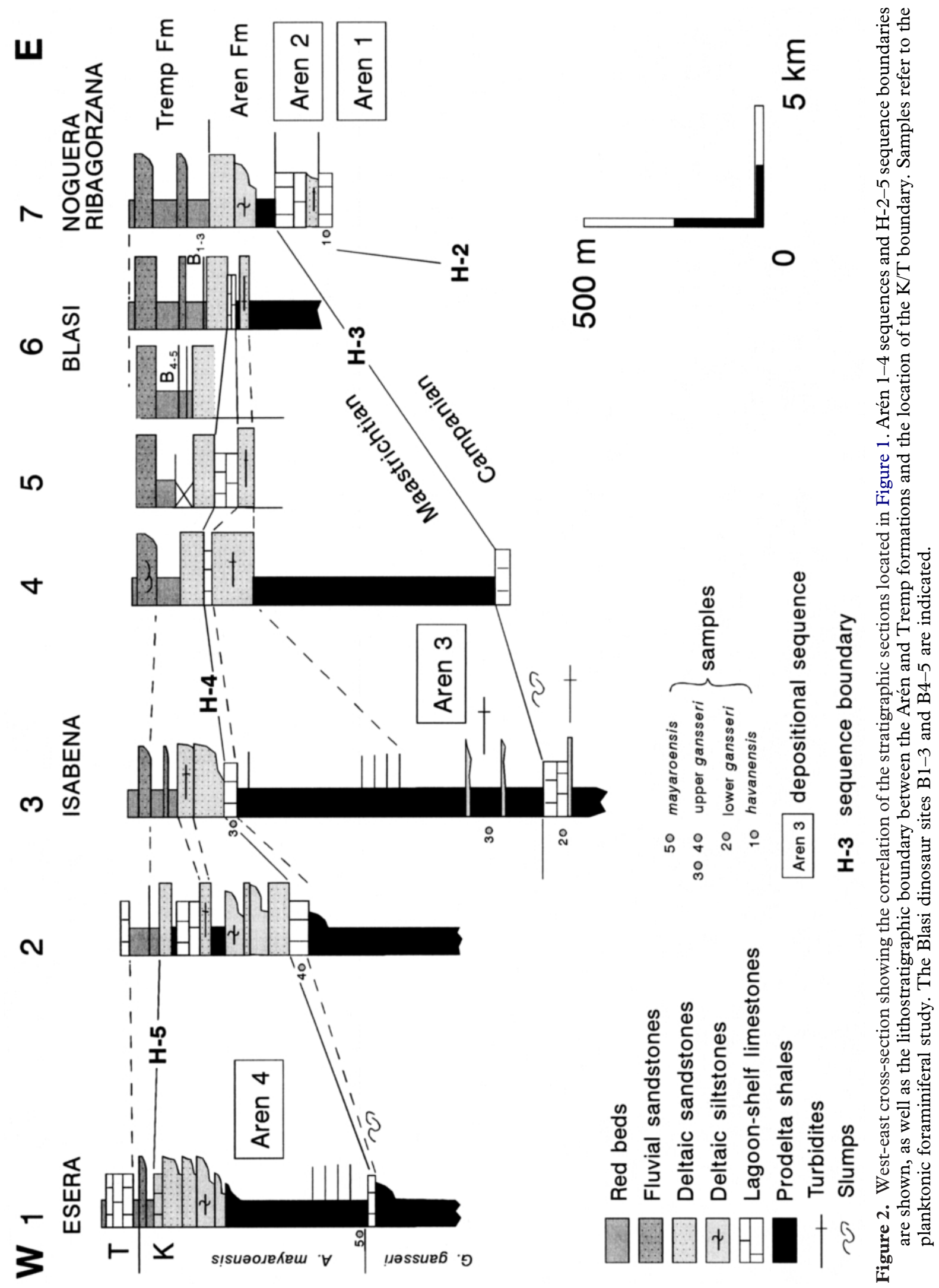




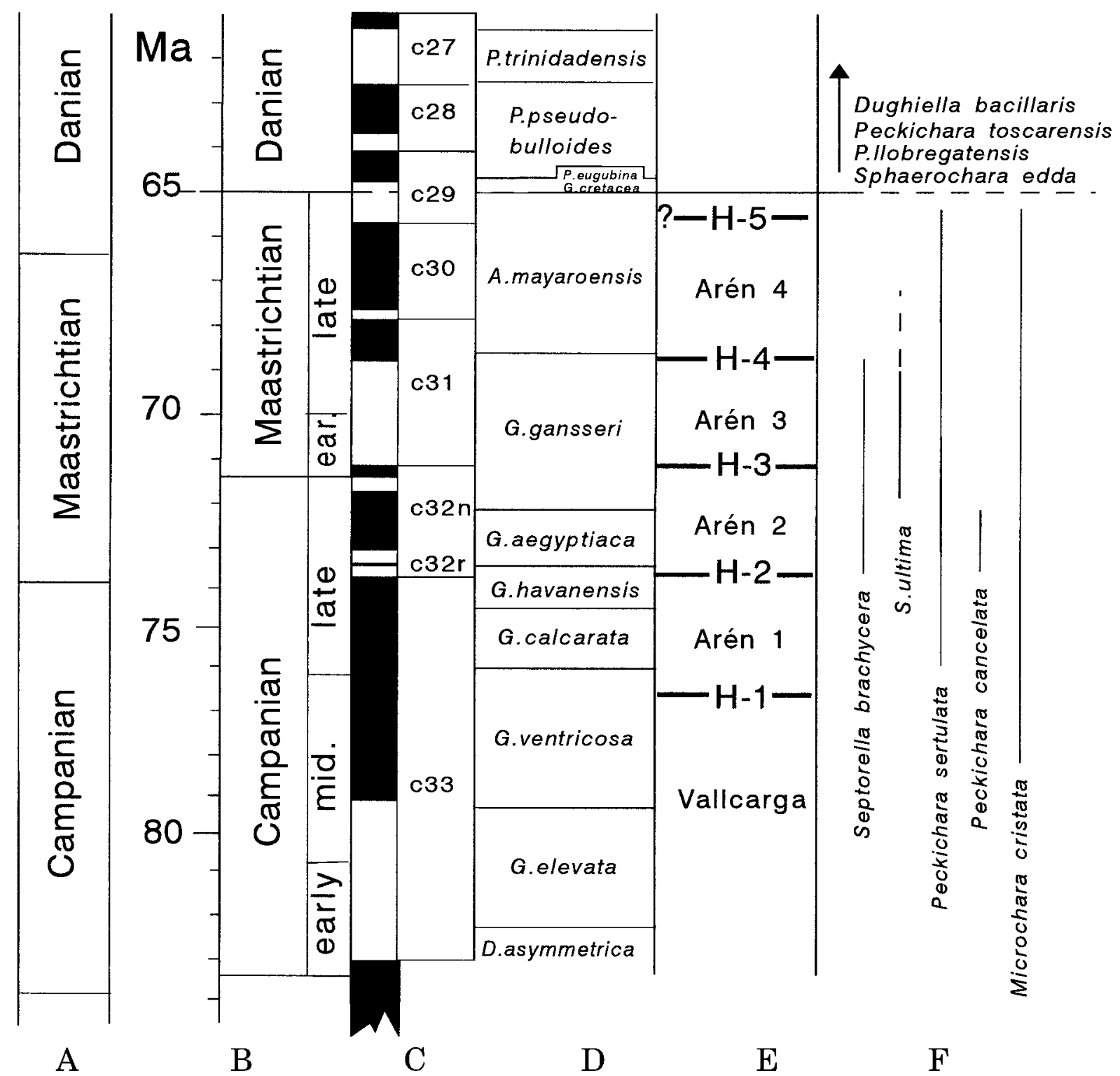

Figure 3. Chronology of the Cretaceous-Tertiary transition in the south-central Pyrenees. The Arén dinosaur sites are located in the Arén 4 sequence. A, chronostratigraphy according to Haq et al. (1987); B, chronostratigraphy according to Gradstein et al. (1995); C, magnetostratigraphy from Cande \& Kent (1995); D, planktonic foraminiferal biostratigraphy according to Robaszynski and Caron (1995); E, sequence stratigraphy from Ardèvol et al. (2000); F, charophyte data modified from Galbrun et al. (1993) and Riveline et al. (1996).

most of the dental battery, and a right surangular. Other skull remains are too fragmentary for proper identification.

Fugal (BLA-99/667, Figures 6, 7). The jugal is a W-shaped gracile bone, very short rostrocaudally (preserved length, $14.5 \mathrm{~cm}$ ). The rostral end is partially broken and it is not possible to determine whether it was broadly convex as in lambeosaurines, or distinctly angular as in hadrosaurines and Telmatosaurus (Weishampel \& Horner, 1990). The rostral process looks short and very expanded ventrally, forming a large articulation surface with the maxilla. The ventral margin is incised and caudally forms a distinctly concave flange ventral to the infratemporal fenestra. The facet for the quadratojugal is not well defined, but seems relatively small. The postorbital and caudal processes are nearly parallel, the former more elongate (albeit incomplete). The joint with the postorbital is a flat surface. The tip of the caudal process is curved rostrally. The mesiodistal length of 


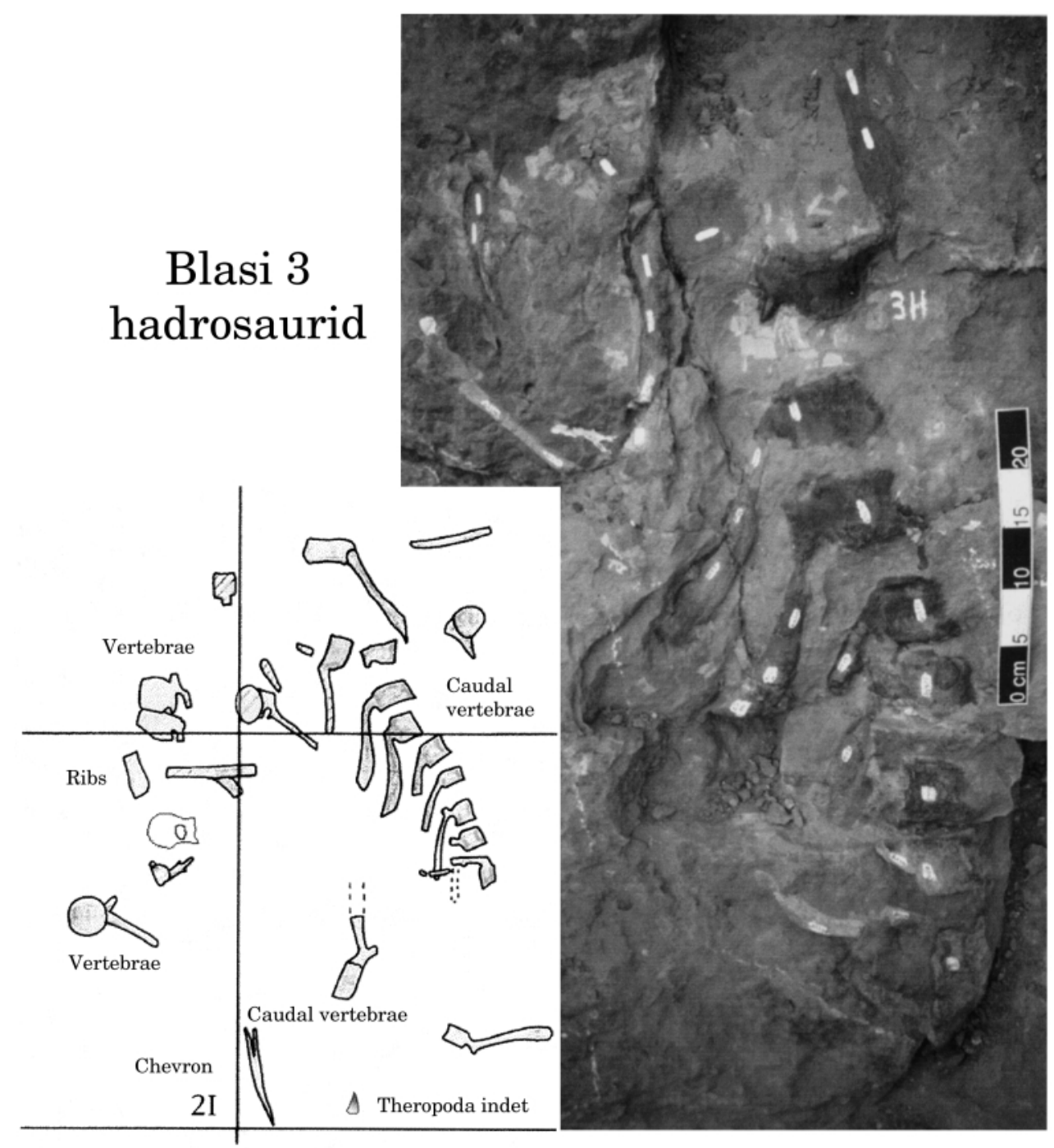

Figure 4. Map and photograph of part of the Blasi 3 dinosaur site, showing articulated caudal vertebrae, ribs and chevrons of a hadrosaurid, and an isolated theropod tooth.

the orbit appears to be comparatively much greater than that of the infratemporal fenestra.

Maxilla (BLA-99/666, Figures 5, 7). Only a fragmentary left maxilla is known (preserved length $13 \mathrm{~cm}$ ). The proximal, dorsal and distal ends are broken. The lateral side is poorly preserved and the articular surface for the jugal is missing. In medial view, the maxillary surface is flat and exhibits a series of special foramina. The maxillary dental battery preserves the last 16 dental positions, five more tooth positions appearing in a proximal displaced fragment. Each tooth position has one or two functional teeth and at least two replacement teeth. The maxillary teeth are narrow mesiodistally and bear a prominent median carina. At least one tooth shows small papillae. The mean mesiodistal length of the teeth is $5.6 \mathrm{~mm}$.
Dentary (BLA-99/665, Figures 6, 7). The left dentary is $33 \mathrm{~cm}$ long and relatively slender. It is roughly rectangular, with parallel dorsal and ventral margins. The rostral portion is ventrally deflected, with a moderate diastema between the predentary surface and the first dentary tooth. The coronoid process is projected rostrally and forms an angle of $75^{\circ}$ with the jaw axis. The lateral side shows a series of small nutritional foramina. A large foramen is present anteroventrally on the symphyseal region. The dental battery is made up of 33 tooth positions, each with 4-5 successional teeth including two well-preserved functional teeth and up to three replacement teeth. The alveolar wall is broken and the enamelled surface of most of the teeth is missing. The mean mesiodistal length of the teeth is $6 \mathrm{~mm}$, only slightly greater than 
that of the maxillary teeth. The crowns are diamondshaped and bear a single median carina. Their height/ length ratio is about 3.5 in the anterior positions. Most of the teeth are straight, apart from those of the ends which are slightly curved distally. The angle between the crown and the root cannot be measured.

Surangular (BLA-99/664, Figures 6, 7). A right surangular is almost complete and relatively large $(11 \mathrm{~cm}$ long as preserved). There is no surangular foramen.

The presence in the Blasi 1 hadrosaurid of a dental battery composed of closely packed tooth families, narrow maxillary teeth, and more than 29 dentary tooth positions are hadrosaurid synapomorphies (Weishampel \& Horner, 1990; Weishampel et al., 1993). The absence of a surangular foramen is common to all hadrosaurids except Protohadros (Head, 1998).

The Blasi 1 hadrosaurid clearly differs from Telmatosaurus transsylvanicus in having a shorter jugal that is more expanded rostrally, narrower dentary teeth not recurved distally, and a single prominent carina in the dentary teeth (Weishampel et al., 1993). It is also more derived than Telmatosaurus and two indeterminate euhadrosaurians from Fontllonga and Valencia (Company et al., 1998; Casanovas et al., 1999a) in having a coronoid process inclined rostrally, a median single carina on the dentary teeth, and a complete absence of secondary ridges on the crowns. Based on these characters, the Blasi 1 hadrosaurid could be assigned to the Euhadrosauria as a member of the clade Hadrosaurinae plus Lambeosaurinae (Weishampel et al., 1993; Casanovas et al., 1999a).

By comparison with the derived hadrosaurids, the Blasi 1 hadrosaur shows a mosaic of both hadrosaurine and lambeosaurine features. The shallow caudal jugal process and its scalloped ventral margin are regarded as synapomorphies for 'brachylophosaur' hadrosaurines (Horner, 1988; Weishampel et al., 1993). On the other hand, the flat and dorsoventrally expanded rostral process, and the height of the postorbital process are reminiscent of lambeosaurines, mainly Hypacrosaurus altispinus (Gilmore, 1924). The presence of very high dentary crowns seems to be more frequent in lambeosaurines than in hadrosaurines (see Horner, 1990; Casanovas et al., 1999a). The Blasi 1 hadrosaurid differs from the lambeosaurine Pararhabdodon of Sant Romà (Figure 1; Casanovas et al., 1999b) in having a less prominent mandibular diastema.

Based on both jugal and dentary characters, the Blasi 1 hadrosaurid may be a new taxon provisionally assigned to Euhadrosauria indet.
Other hadrosaurid material from Blasi 2 and 3. There is no evidence of the occurrence of more than one hadrosaurid species in the Arén sites, but the material is probably too scanty and fragmentary for an accurate account. Isolated hadrosaurid teeth have been recovered from Blasi 2 and 3 (Figure 8). Dentary teeth are similar to those of Blasi 1 . Shed maxillary crowns from Blasi 2 may have a strong carina, more prominent than that of the maxillary teeth from Blasi 1.

Hadrosaurid postcranial remains from Blasi sites consist of portions of the vertebral column (including articulated parts) and bones from the appendicular skeleton; the vertebrae show typical hadrosaur features, such as the strongly opisthocoelous cervical centra and amphiplatyan dorsal and caudal vertebrae; the caudal centra bear double separate facets for the chevrons, which form an angle equivalent to that of neural spines (Figure 4; Weishampel \& Horner, 1990). The neural spines of the proximal caudals are relatively tall and caudally angled as in Pararhabdodon, in contrast to Telmatosaurus (Figure 4; compare with Weishampel et al., 1993 and Casanovas et al., 1999b). A hadrosaurine-like, slender, incomplete humerus bears a modestly developed, angular, deltopectoral crest. A rather complete femur, $73 \mathrm{~cm}$ long, lacking the distal condyles, is straight as is usual in hadrosaurids. This suggests a body length of about $6 \mathrm{~m}$. Other preserved elements are: a proximal fragment of ulna, a distal end of tibia, a III metatarsal and a phalanx.

\subsection{Sauropods}

An isolated tooth in Blasi 2 documents the presence of a sauropod, already attested by eggshells. The material is too scanty for accurate identification.

\subsection{Theropods}

Theropods are represented by three types of isolated teeth from Blasi 2 and 3 (Figure 9, Table 2). Dromaeosauridae indet. $\mathrm{A}$ is a large form from Blasi 3, the distal denticles being bigger than the mesial (3 vs. 5 denticles per mm: Currie et al., 1990); since the distal denticles are inclined it may belong to the Velociraptorinae (sensu Rauhut \& Werner, 1995). Small teeth fragments from Blasi 2 could belong to this taxon.

Dromaeosauridae indet. $\mathrm{B}$ is another small dromaeosaurid from Blasi 2. It differs from type A in having only distal denticles, which are not inclined, and 6-16 denticles per $\mathrm{mm}$. The small size and straight form of the denticles suggest affinities with the 

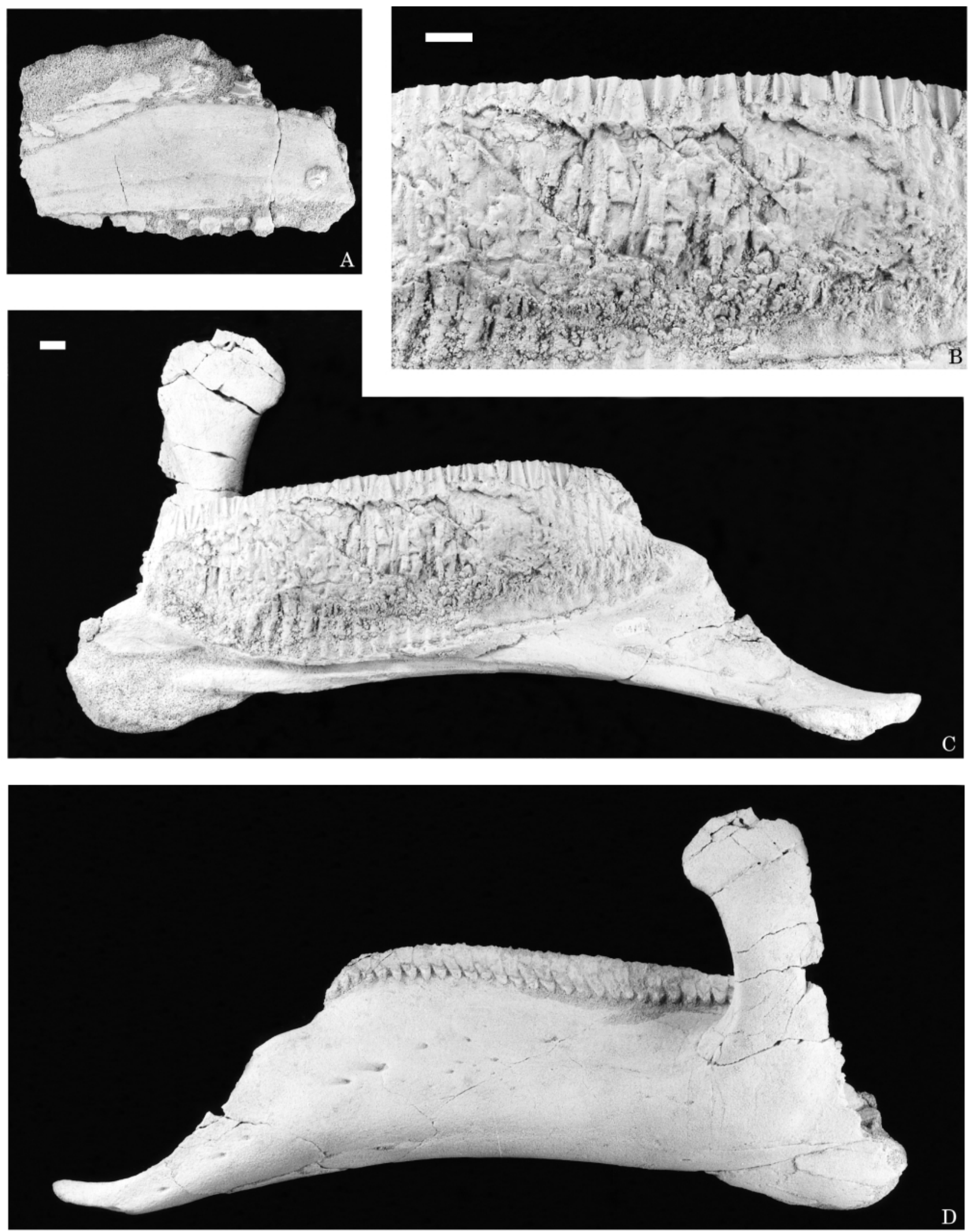

Figure 5. Euhadrosauria indet.: skull bones and lower jaw from Blasi 1 (Arén, Huesca; Late Maastrichtian). A, left maxilla (MPZ 99/666); B-D, left dentary (MPZ 99/665): A, D, lateral views; B, C, medial views. Scale bars represent $10 \mathrm{~mm}$. 

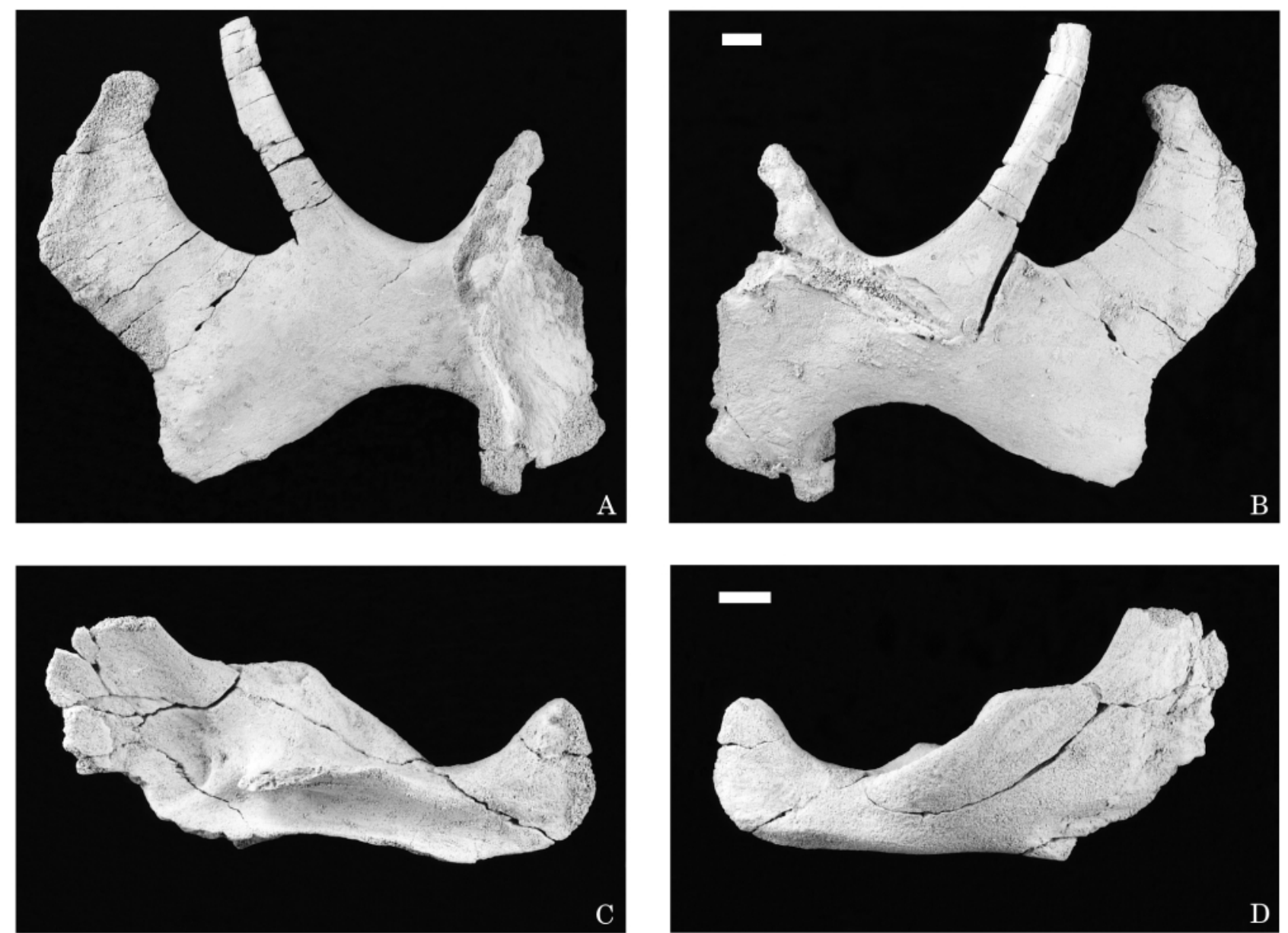

Figure 6. Euhadrosauria indet.: skull bones and lower jaw from Blasi 1 (Arén, Huesca; Late Maastrichtian). A, B, left jugal (MPZ 99/667); C, D, right surangular (MPZ 99/664): A, C, medial views; B, D, lateral views. Scale bars represent $10 \mathrm{~mm}$.

Dromaeosaurinae (Currie et al., 1990). Dromaeosaurids are a common group of theropods in Upper Cretaceous deposits of southern and central Europe (see Csiki \& Grigorescu, 1998).

Small unserrated teeth from Blasi 2 with vertical crests are attributed to cf. Euronychodon sp. (Antunes \& Sigogneau Russell, 1991). The status of Euronychodon is uncertain. It represents a peculiar, small coelurosaurian theropod having close affinities with either maniraptorans or ornithomimosaurs (see Csiki \& Grigorescu, 1998).

Other similar teeth from Blasi 2 but without crests, here assigned to Coelurosauria indet., may correspond to one of these small forms or to a different type.

\subsection{Eggshells}

Blasi 2 has provided about 200 eggshell fragments of at least seven types (López-Martinez et al., 1999a).
One type is $0.75 \mathrm{~mm}$ thick and has an undulating external surface with scattered depressions, a tubospherulitic structure, mamillary cores well-separated from each other, and shell units that coalesce upwards. It is similar in construction but thinner than Megaloolithus pseudomamillare, a Megaloolithidae with coalescent shell units found in Peru, France and Spain (Vianey-Liaud \& López-Martínez, 1997; Vianey-Liaud et al., 1997). The oofamily Megaloolithidae is attributed to sauropod titanosaur dinosaurs (Chiappe et al., 1998).

The other six eggshell-types have 'ornithoid' prismatic structure. This ootype has been found associated with embryos of theropod dinosaurs and birds (Varrichio et al., 1997). They measure 0.6$0.18 \mathrm{~mm}$ in thickness and differ in their mamillary core, prism and micropore patterns, type of external surface sculpture, and presence or absence of an external zone. 


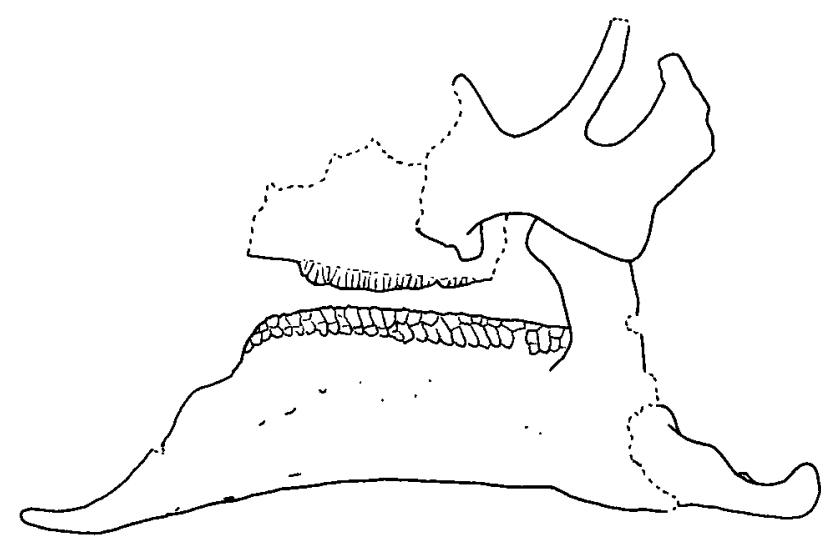

Figure 7. Euhadrosauria indet. from Blasi 1 (Arén, Huesca). Reconstruction of the skull and lower jaw in left lateral view (right surangular reversed). Scale bar represents $50 \mathrm{~mm}$

\section{Other vertebrate remains}

The Arén vertebrate fossils also include remains of actinopterygians, amphibians, squamates, turtles and crocodilians, mostly found at Blasi 2 (Table 1). Actinopterygians are represented by lepisosteiforms (ganoid scales and teeth), pycnodontiforms (teeth) and indeterminate teleosteans. The herpetofauna is represented by indeterminate amphibians, squamates (teeth from lizards and possible iguanids) and abundant turtle and crocodilian remains.

The remains of turtle shell plates and plate fragments are referable to a single pleurodiran taxon. The ornamentation of the plates is smooth with very fine, dichotomized sulci, typical of bothremydids such as Polysternon and Elochelys (Lapparent \& Murelaga, 1996). The size of the plates indicates a rather thick carapace about $30 \mathrm{~cm}$ long and $25 \mathrm{~cm}$ wide. It suggests that they belong to cf. Polysternon sp., already found in Lower Maastrichtian deposits at Fontllonga 6 (Ager syncline: Murelaga et al., 1998). This genus is common in Campanian and Maastrichtian freshwater deposits of the Ibero-Armorican realm, but it is also found in coastal deposits, because these turtles would have made use of marine littoral streams to migrate (Broin, 1977; Lapparent \& Murelaga, 1996).

Crocodilian remains consist mostly of isolated teeth and osteoderms. The tooth shapes indicate at least three different forms in the assemblage: (1) a tribodont (button-like) form from Blasi 2 is similar to those of the small alligatorid Acynodon, hitherto known from Spain and France (Buscalioni et al., 1997); (2) a striated, 'trematochampsid'-like form from Blasi 2; and (3) smooth, conical teeth from Blasi 1 and 2 that probably represent an alligatoroid.

\section{The charophytes}

\subsection{Assemblage composition}

The Blasi 2 charophyte assemblage includes four species: Feistiella sp. nov. (Porocharaceae), Amblyochara concava ssp. Grambast-Fessard, Amblyochara sp. A Feist and Peckichara sertulata Grambast (Characeae).

The new species of Feistiella is referable to the genus on the basis of its small apical pore, which is always open, and its undivided basal plate. The subglobular middle-sized gyrogonites differ from all the described species of Feistiella and of Porochara, whose basal plates have not been described. Feistiella has been reported from Berriasian-Upper Maastrichtian strata (Schudack, 1986); moreover, new material from the Dano-Montian locality of Péloua in the Northern Pyrenees (Massieux et al., 1989) has revealed the persistence of the genus during the Early Tertiary.

Amblyochara concava ssp. Grambast-Fessard is assigned to Amblyochara on the basis of its undifferentiated apical part, the concave spiral cells and the very thin basal plate, and to $A$. concava because of its subglobular general shape and the protruding junction line of the spirals at the apex. The gyrogonite shape resembles that of the type species from the Montian Mons locality, which is however, larger (Table 3). The size of the Blasi species recalls $A$. concava mucronata Feist from Barranco de La Posa, in the Tremp Basin (Feist \& Colombo, 1983), now attributed to the latest Campanian, but it differs in being more globular.

Amblyochara sp. A Feist is characterized by large $(1050-1080 \times 1150-1100 \mu \mathrm{m})$, ovoid gyrogonites having barely visible spiral sutures and a slightly tapering base. It has been reported under the name A. begudiana from the Upper Maastrichtian 'Marnes d'Auzas' in southern France (Massieux et al., 1979), as well as from the Fontllonga section where it occurs in three uppermost Maastrichtian levels of the Tremp Formation (chrons C31n to C29r; Galbrun et al., 1993, fig. 6).

The Blasi Peckichara specimens are referable to $P$. sertulata on account of their general shape and dimensions. They differ in that the intercellular crest is thick or double instead of lamellar as in the type material from the upper Rognacian of southern France (Grambast, 1971; Westphal \& Durand, 1990). Hence they recall Peckichara sp. 1 Feist, which occurs in chron $\mathrm{C} 30 \mathrm{n}$ in the Fontllonga section (Late Maastrichtian; Galbrun et al., 1993). The latter species is, however, larger and the morphology of the basal part differs. Peckichara sertulata ranges from Late Campanian to Late Maastrichtian (Figure 3; Galbrun et al., 1993; Riveline et al., 1996). 

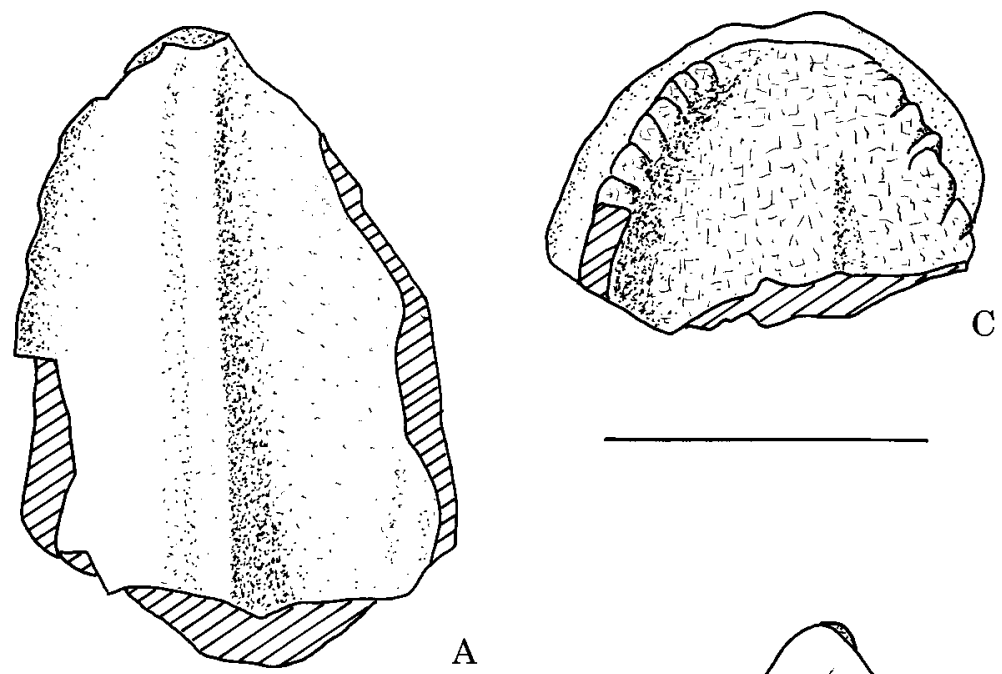

A

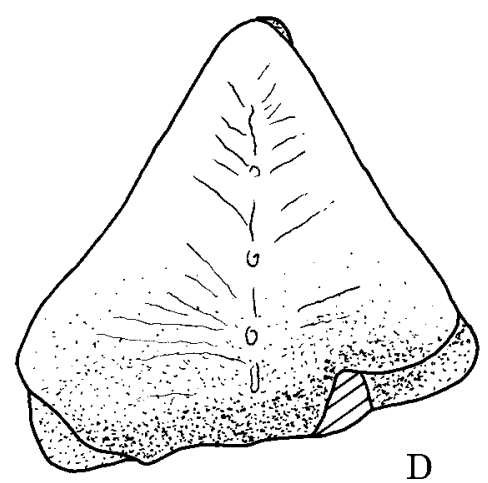

Figure 8. Isolated hadrosaurid teeth from Blasi 2. A, left dentary tooth (MPZ 99/668) in lingual view. B, shed maxillary tooth (MPZ 99/669) in occlusal view. C, right maxillary tooth (MPZ 99/670) in labial view. D, shed maxillary tooth (MPZ 99/671) in occlusal view. Scale bar represents $5 \mathrm{~mm}$. Note the papillae and rough enamel in MPZ 99/670, and the absence of papillae and smooth enamel in MPZ 99/668.

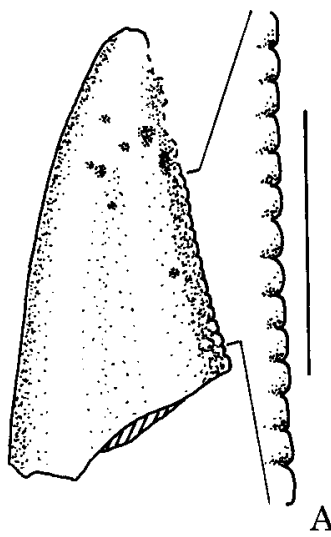

A

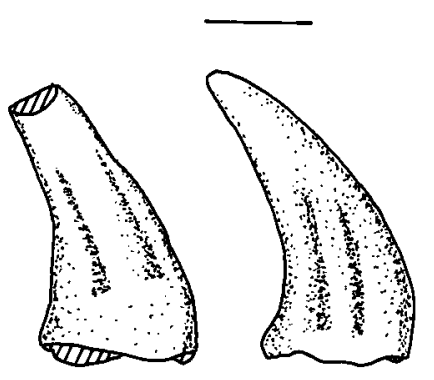

B

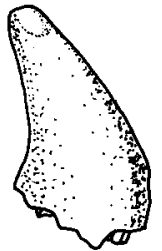

$\mathrm{C}$
D

Figure 9. Theropod teeth from Blasi 2. A, Dromeosauridae indet., type B (MPZ 98/72), with detail of distal denticles. B, cf. Euronychodon sp. (MPZ 98/76). C, cf. Euronychodon sp. (MPZ 98/77). D, Coelurosauria indet. (MPZ 98/82). Views $\mathrm{A}$ and $\mathrm{D}$ are labial/lingual; $\mathrm{B}$ and $\mathrm{C}$ are lingual. Note the pits on the enamel of MPZ 98/72, possibly related to corrosion by digestion, and the wear facet in MPZ 98/82. Scale bars represent $1 \mathrm{~mm}$.

\subsection{Biostratigraphic and palaeoecological indications}

According to the ranges of the four species (Table 4), the age of the Blasi assemblage appears to be Late
Maastrichtian. The peculiar morphology of the Blasi representative of $P$. sertulata, recalling $P$. sp. 1 , is compatible with the young dating suggested by the marine fossils (see below). 


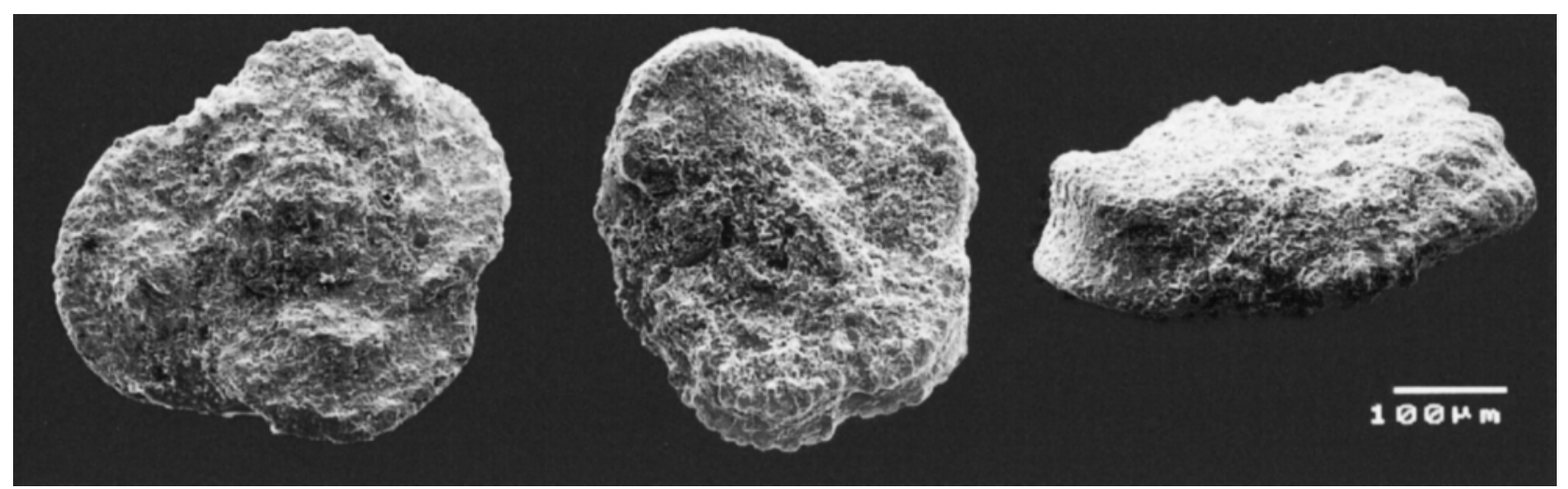

Figure 10. The planktonic foraminifer Abathomphalus mayaroensis from the Esera valley (Arén 4 sequence, sample 5, section 1; Figure 2). A, spiral side; B, umbilical side; C, lateral view.

In contrast to most charophyte species, which occupy freshwater biotopes, representatives of the Porocharaceae can tolerate a wide range of salinities, from freshwater-oligohaline to brachyhaline (Schudack et al., 1998). In the Pyrenees, Feistiella has been found previously only at the base of the Tremp Formation, in contact with the marine Arén Sandstone [F. ('Porochara') oblonga Grambast in Llimiana, and F. ('Porochara') malladae (Bataller) in Barranco de la Posa (Feist \& Colombo, 1983)]. Thus, the Blasi 2 assemblage confirms its transitional position between marine and freshwater deposits, indicating saline influences in the Blasi 2 area.

\section{Dating the Arén dinosaur sites}

Marine-continental correlations can be physically traced from east to west along the northern flank of the Tremp syncline, owing to the excellent exposure. The dinosaur-bearing strata have been dated by means of planktonic foraminifera, present in laterally equivalent basinal deposits. We follow here the depositional-sequence framework introduced by Ardèvol et al. (2000), which distinguish four westward-prograding depositional sequences, Arén 1-4 (Figure 2). Each sequence builds a clinoform made up of basinal turbidites, deltaic deposits and continental red beds. The locations of micropalaeontological samples and the foraminiferal assemblages that enable these four depositional sequences to be dated, are shown here. In addition, magnetostratigraphy, charophyte and palynomorph data have been taken into account.

The upper interval of the Arén 1 depositional sequence contains foraminifera from the Globotruncanella havanensis Biozone (sample 1, section 7; Figure 2). The new biostratigraphic scale divides the former Globotruncana falsostuarti Biozone into Globotruncanella havanensis and Globotruncana aegyptiaca biozones, and places them in the Late Campanian instead of the Early Maastrichtian (Robaszynski \& Caron, 1995; Gradstein et al., 1995).

The Arén 2 sequence can be assigned to the Globotruncana aegyptiaca Biozone and the lower part of the Gansserina gansseri Biozone, because the upper interval of this sequence has provided the foraminifera Contusotruncana fornicata, C. walfischensis, Globotruncana arca, G. ventricosa, Globotruncanita stuarti, G. stuartiformis, Pseudotextularia nuttalli, Rugoglobigerina milamensis, and others (sample 2, section 3; Figure 2).

The lower interval of the Arén 3 sequence contains planktonic foraminifera from the upper Gansserina gansseri Biozone (lower sample 3, section 3; Figure 2). Consequently, the $\mathrm{H}-3$ sequence boundary between the Arén 2 and Arén 3 sequences is situated in the middle part of the Gansserina gansseri Biozone, which approximately coincides with the Campanian/ Maastrichtian boundary (Figure 3).

Towards the upper part of Arén 3 sequence, the planktonic foraminifera decrease from about 20 to 12 species, among those present being Globotruncana arca, Globotruncanita stuarti, Pseudotextularia nuttalli, Pseudoguembelina palpebra, Planoglobulina brazoensis and $P$. acervulinoides. The uppermost interval of the Arén-3 sequence has been attributed to Abathomphalus mayaroensis Biozone by García Senz et al. (in press). However, additional sampling has led to the rejection of this age. Instead, it is taken to correspond to the highest part of the Gansserina gansseri Biozone, based on rich samples with more than 30 planktonic species, among which are Contusotruncana walfischensis, $P$. acervulinoides, $P$. multicamerata, Pseudotextularia intermedia, Racemiguembelina fructicosa, R. powelli, Rugoglobigerina hexacamerata and 
Table 1. Faunal list of the vertebrates from Arén sites, Late Maastrichtian, Huesca Province, southern Pyrenees.

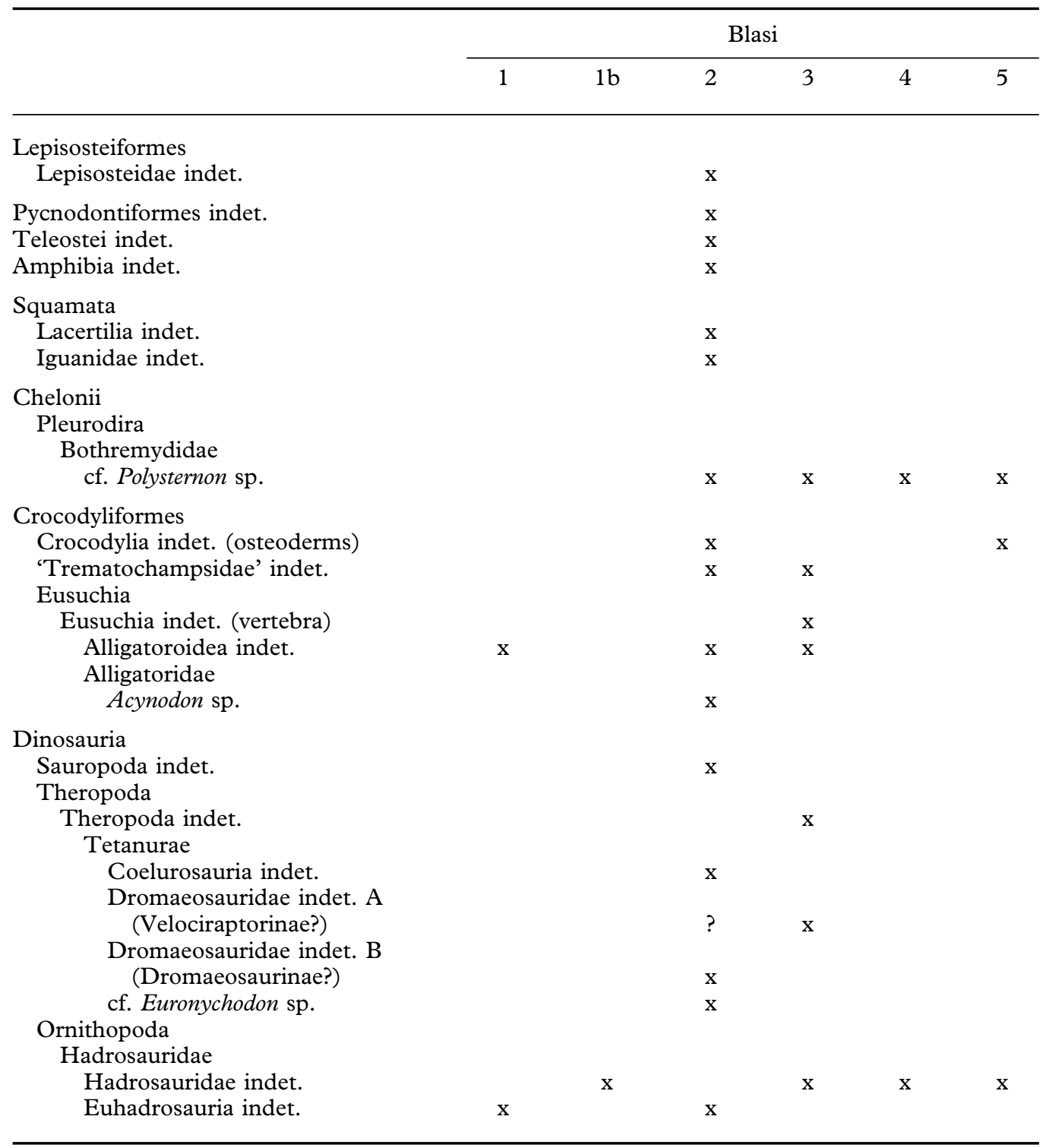

R. milamensis (upper sample 3, section 3, and sample 4 , section 2; Figure 2). Consequently, the age of the Arén 3 sequence ranges from Early to early Late Maastrichtian (Figure 3).

The lowermost interval of the Arén 4 sequence approximately coincides with the appearence of Abathomphalus mayaroensis (latest Maastrichtian Biozone), since it has provided at least 32 species of planktic foraminifera, among them being Abathomphalus mayaroensis, Contusotruncana contusa, C. walfischensis, Planoglobulina acervulinoides, Pseudotextularia intermedia, Racemiguembelina fructicosa and Rugoglobigerina hexacamerata (sample 5, section 1; Figure 2). This interval is above the Horizon-4 sequence boundary, which can be traced landward about $60 \mathrm{~m}$ below the Blasi 1 site (Figure 2).

The upper boundary of the Arén 4 sequence in the Esera valley (Horizon 5) coincides with the top of the Arén Formation (section 1; Figure 2), dated as Late Cretaceous on the basis of fossil content (Garrido Mejías \& Ríos Aragües, 1972). Consequently, the Arén 4 sequence and its dinosaur sites described in this paper are situated in the Abathomphalus mayaroensis Biozone, dated as latest Maastrichtian. The Blasi 1-3 sites correlate with the lower part of this biozone, thus around $68 \mathrm{Ma}$, and the Blasi 4-5 sites with the middle part, about $67 \mathrm{Ma}$ (Figures 2, 3). The $A$. mayaroensis Biozone in the Tremp Basin reaches its 
Table 2. Measurements in $\mathrm{mm}$ and characters of Theropoda from Arén; FABL, fore-aft basal length.

\begin{tabular}{|c|c|c|c|c|c|c|c|}
\hline Site & Code & Name & FABL & height & basal width & $\begin{array}{c}\text { dent } / \mathrm{mm} \\
\text { mesial }\end{array}$ & $\begin{array}{l}\text { dent } / \mathrm{mm} \\
\text { distal }\end{array}$ \\
\hline \multirow[t]{2}{*}{ Blasi 3} & MPZ98-67 & Theropoda indet. & 27 & $>27.5$ & 13 & broken & broken \\
\hline & MPZ98-68 & Dromeosauridae indet. (Velociraptorinae?) & 16 & $>18$ & - & $4.83-5.23$ & $2.81-3.01$ \\
\hline \multirow[t]{14}{*}{ Blasi 2} & MPZ98-69 & Theropoda indet. & - & 1.7 & - & - & 2.81 \\
\hline & MPZ98-70 & Theropoda indet. & - & 2.3 & - & - & 3.74 \\
\hline & MPZ98-71 & Theropoda indet. & - & 1.5 & - & - & 4.18 \\
\hline & MPZ98-72 & Dromeosauridae indet. (Dromeosaurinae?) & 2.23 & 4.32 & 1.07 & - & 7.57 \\
\hline & MPZ98-73 & Dromeosauridae indet. (Dromeosaurinae?) & 2.19 & 3.35 & 0.93 & - & $\begin{array}{c}6.54 \mathrm{mid} \\
13.15 \text { base } \\
10.87 \text { all }\end{array}$ \\
\hline & MPZ98-74 & Dromeosauridae indet. (Dromeosaurinae?) & 1.39 & 3.02 & 0.6 & - & irregular 8.77 \\
\hline & MPZ98-75 & Dromeosauridae indet. (Dromeosaurinae?) & 1.39 & 2.65 & 0.74 & - & $8.2-10.87$ \\
\hline & MPZ98-76 & cf. Euronychodon sp. & 1.49 & 2.74 & 0.6 & - & 15.87 \\
\hline & MPZ98-77 & cf. Euronychodon sp. & 1.39 & 2.79 & 0.6 & - & - \\
\hline & MPZ98-78 & cf. Euronychodon sp. & 1.21 & 2.23 & 0.84 & - & - \\
\hline & MPZ98-79 & Coelurosauria indet. & 1.86 & 1.86 & 1.02 & - & - \\
\hline & MPZ98-80 & Coelurosauria indet. & 1.81 & 2.56 & 0.88 & - & - \\
\hline & MPZ98-81 & Coelurosauria indet. & 1.39 & 1.91 & 0.74 & - & - \\
\hline & MPZ98-82 & Coelurosauria indet. & 1.21 & 2.42 & 0.74 & - & - \\
\hline
\end{tabular}

Table 3. Comparison of the Amblyochara concava ssp. from Blasi 2 with the two subspecies of A. concava.

\begin{tabular}{lcccc}
\hline Amblyochara & $\begin{array}{c}\text { length } \\
\mu \mathrm{m}\end{array}$ & $\begin{array}{c}\text { width } \\
\mu \mathrm{m}\end{array}$ & $\begin{array}{c}\text { ISI } \\
(1 / \mathrm{w} \times 100)\end{array}$ & $\begin{array}{c}\mathrm{N} \\
\text { (number of spirals visible in profile) }\end{array}$ \\
\hline $\begin{array}{l}\text { A. concava concava } \\
\text { A. concava ssp. }\end{array}$ & $950-1150$ & $950-1300$ & $90-102$ & $7-8$ \\
A. concava mucronata & $500-750$ & $575-760$ & $82-135$ & $7-9$ \\
$725-950$ & $70-90$ & $5-7$ \\
\hline
\end{tabular}

maximum thickness, being about $200-250 \mathrm{~m}$ in the Blasi section and more than $650 \mathrm{~m}$ in the Esera valley (sections 1 and 6; Figure 2).

According to the fossil content of the Esera and Isábena sections, the position of the Cretaceous/ Tertiary boundary is situated in the middle part of the Tremp Formation, about $50 \mathrm{~m}$ above the top of Arén Formation. This is based on the occurrence of autochtonous rudists and the ammonite Pachydiscus gollevillensis $48 \mathrm{~m}$ above the Arén Formation in the Esera section (Eichenseer, 1988), and dinosaur sites in stratigraphically equivalent rocks in the Isábena section. The H-5 sequence boundary and the lower part of the overlying depositional sequence is therefore situated in the uppermost Cretaceous. The position of the Cretaceous/Tertiary boundary in the Tremp Basin agrees with that of the Ager valley, situated near the lower/middle boundary of the Tremp Formation (López-Martínez et al., 1998). There is no basis, therefore for a Tertiary age determination for the top of the Arén 4 sequence as suggested by FondecaveWallez et al. (1990) and Galbrun et al. (in press). The method used by the former ('grade-dating' analysis) is based on the assumption that the selected foraminiferal lineage evolved gradually, but the results of this method have already been rejected in Northern Pyrenees by Bilotte et al. (1999). Galburn et al. interpreted as chron $\mathrm{C} 28 \mathrm{r}$ a long reverse magnetozone across the transition between the Aren and Tremp Formations, which in fact ties in better with chron C29r.

\section{Other Maastrichtian dinosaur localities in the south-central Pyrenees}

Previous dinosaur discoveries in the south-central Pyrenees dated as Late Maastrichtian have been reported to the east of Arén (Lleida, Figure 1). On the northern limb of the Tremp syncline, the Els Nerets site (=Vilamitjana; Casanovas et al., 1987), with 
Table 4. Chronological ranges of the charophyte species from Blasi 2.

\begin{tabular}{l|l|l|l|l}
\hline Stages & Feistiella sp. & Amblyochara concava ssp. & Amblyochara sp. A & Peckichara sertulata \\
\hline Dano-Montian & & & & \\
\hline Latest Maastrichtian & & & & \\
\hline Early Late Maastrichtian & & & & \\
\hline Early Maastrichtian & & & & \\
\hline
\end{tabular}

titanosaurid and hadrosaurid remains, occurs in the uppermost interval of the Arén 2 sequence, dated as latest Campanian (Ardévol et al., 2000; see above and Figures 1, 2). The Sant Romà site, with only hadrosaurids (type locality for Pararhabdodon isonensis; see Casanovas et al., $1999 \mathrm{~b}$ and references therein) is $70 \mathrm{~m}$ below lacustrine limestones dated Late Maastrichtian on the basis of charophytes (Peckichara sertulata, Maedleriella sp. A and Peckichara with tubercles; Feist \& Colombo, 1983).

On the southern limb of the Tremp syncline, sites at Moror and Barcedana have provided sauropod and hadrosaurid bones (Figure 1). These are below grey marl beds with two charophyte species of the genus Septorella (Brinkmann, 1984; Masriera \& Ullastre, 1988). Septorella brachycera disappears within the early Chron C31n (Galbrun et al., 1993; Riveline et al., 1996; about $68.5 \mathrm{Ma}$ according to Cande \& Kent, 1995), just below the Abathomphalus mayaroensis datum (Pujalte et al., 1995; Figure 3); thus these sites cannot be younger than early Late Maastrichtian.

Westward from Arén, large titanosaurids have been reported from Serraduy (Huesca, Canudo et al., 1999). They correspond to the upper part of the Arén 4 sequence of latest Maastrichtian age (upper Abathomphalus mayaroensis Biozone; Figure 2).

South of the Montsec thrust, the Fontllonga site in the Ager syncline (Figure 1) has yielded a hadrosaurid dentary, dated in the highest part of Chron C30n (latest Maastrichtian, about $66 \mathrm{Ma}$; Casanovas et al., $1999 b$ ). In this area, dinosaur footprints have been recorded on uppermost Maastrichtian rocks close to the Cretaceous/Tertiary boundary, dated in Chron C29r, $15 \mathrm{~m}$ above the hadrosaur site and $3 \mathrm{~m}$ below both a $\delta^{13} \mathrm{C}$ isotopic anomaly and Paleocene fossil sites (López-Martínez et al., 1998, 1999b; Peláez-Campomanes et al., 2000).

Summarizing, other dinosaur sites in the southcentral Pyrenees have yielded: (1) titanosaurs and hadrosaurs (Pararhabdodon) ranging in age from latest Campanian (Els Nerets) to Early Maastrichtian (Moror and Barcedana); (2) two different hadrosaurs (Pararhabdodon and a primitive Euhadrosaur dated as Late Maastrichtian; Sant Romà and Fontllonga); (3) a large sauropod from the latest Maastrichtian (Serraduy); and (4) diverse dinosaur footprints high in chron C29r, reaching the top of the Cretaceous. These records show the continuity and sustained diversity of dinosaur fauna in the Spanish Pyrenees during the Late Maastrichtian, now reinforced with four more taxa from the new Blasi sites (a third hadrosaur and three theropods). Moreover, there is a coincidence between the highest stratigraphic record of the Spanish dinosaurs and the Cretaceous/Tertiary boundary, marked by the younger part of chron C29r and a $\delta^{13} \mathrm{C}$ isotopic anomaly.

\section{Other Maastrichtian dinosaur localities in Europe}

Latest Cretaceous dinosaur sites have been extensively reported from many parts of Europe: Petites-Pyrénées; Plantaurel, Hautes-Corbières, BasLanguedoc (French Pyrenees); Aix en Provence (France); Transylvania (Romania); Limburg (Netherlands, Belgium); Bavaria (Germany) and Crimea (Ukraine). Some uncertainty exists concerning the accurate dating of the sites because many of them occur in non-marine rocks which cannot be correlated with marine deposits; moreover, where associated marine fossils exist, their stratigraphic 
ranges are often ill-defined. The chronological evidence is discussed here in relation to the timescale of Gradstein et al. (1995).

In southern Europe, some dinosaur sites from the northern Pyrenees and Provence have been dated as Late Maastrichtian on the basis of the occurence of the charophyte Septorella (Buffetaut \& Le Loeuff, 1991; Buffetaut et al., 1997; Gheerbrant et al., 1997; Laurent et al., 1999), but this genus in fact appeared in Late Campanian and disappeared early in the Late Maastrichtian, before the arrival of Abathomphalus mayaroensis (see above, Figure 3).

This observation applies to the Le Jadet and Lestaillats sites in the Petites Pyrénées, which has yielded dinosaurs (hadrosaurids, nodosaurids and theropods), crocodilians, turtles and actinopterygians (Paris \& Taquet, 1973; Buffetaut \& Cavin, 1995; Laurent et al., 1999). These sites occur in calcarenites below the 'Marnes d'Auzas', which are more than $200 \mathrm{~m}$ thick in the type section and contain Septorella near the top (Bilotte et al., 1983; Bilotte, 1985; Lepicard, 1985; Lepicard et al., 1985; Breton et al., 1995). Hence, the age of these dinosaur sites is probably greater than Early Maastrichtian (Figure 3). Other dinosaur sites with indeterminate hadrosaurids and theropods have been found in the basal part of the 'Marnes d'Auzas' (Peyrecave A and B, Tricouté 1 and 2, Auzas; Gheerbrant et al., 1997); they contain both species of Septorella and, therefore, range in age from Late Campanian to early Late Maastrichtian. Finally, the upper part of the Marnes d'Auzas contains only one Septorella species or none; as a result it may be dated as mid-late Late Maastrichtian; this is the case of the Mérigon site (Ariège) with remains of turtles, crocodilians, pterosaurs and hadrosaurid dinosaurs and the charophytes Microchara cristata and Maedleriella sp. A (Bilotte, 1985; Lepicard et al., 1985; Tambareau et al., 1997; Buffetaut et al., 1997; Figure 3).

The last occurrence of the charophyte Septorella ultima is considered to be coeval with that of Septorella brachycera (early Late Maastrichtian, about $69 \mathrm{Ma}$, Riveline et al., 1996; Figure 3). However, the record of $S$. ultima in several localities where $S$. brachycera is absent suggests that it survived longer (Figure 3). The Le Bexen site (eastern Corbières; Laurent et al., 1997), which has provided chelonians, crocodilians, pterosaurs, and hadrosaurid (Pararhabdodon sp.) and dromaeosaurid dinosaurs, has yielded only Septorella ultima and may thus be mid Late Maastrichtian age.

The Languedoc-Provence dinosaur sites have not yet provided reliable evidence of age despite some tentative magnetostratigraphic correlations (Westphal \& Durand, 1990; Galbrun, 1997). In the Aix Basin
(Provence), the Vitrolles-Couperigne dinosaur site has yielded an ornithopod skeleton (Rhabdodon priscus), dromeosaurid teeth and three types of eggshells (Garcia et al., 1999). It has been dated as Early Maastrichtian on the basis of the presence of the charophyte Peckichara cancellata (early 'Rognacian'); in fact, recent recalibration of the range of this species places it entirely within the Late Campanian (Riveline et al., 1996).

In Eastern Europe, dinosaurs are known mainly from the Romanian Haţeg Basin and from Sebes, Transylvania (Grigorescu, 1992). Several scattered localities in red beds that are $>1000 \mathrm{~m}$ thick have yielded sauropods (the titanosaurid Magyarosaurus), four theropods (dromaeosaurids, troodontid-like small theropods, cf. Euronychodon, and neoceratosaurs), ornithopods (the euornithopod Rhabdodon and the hadrosaurid Telmatosaurus) and ankylosaurs (the nodosaurid Struthiosaurus) together with fishes, amphibians, turtles, crocodilians, pterosaurs and mammals (Weishampel et al., 1991, 1993; Grigorescu et al., 1994; Csiki \& Grigorescu, 1998). These sites have been considered to be Late Maastrichtian on the grounds that the youngest underlying marine deposits are Late Campanian-Early Maastrichtian; in fact the age-range of the foraminifer Lepidorbitoides minor, for long considered to be a Maastrichtian marker species, is Late Campanian according to recent calibrations (lower Gansserina gansseri Biozone; Caus et al., 1988). The middle part of the dinosaur-bearing red beds is supposed to be Maastrichtian because it contains the palynomorph Pseudopapillopollis praesubhercynicus (Weishampel et al., 1991; Grigorescu et al., 1994); however this criterion is unreliable, because there is a continuous succession of palynomorph taxa across the Cretaceous/Tertiary transition in the Tethys area, the stratigraphic ranges of which are imprecisely known (Méon, 1991; Médus et al., 1992; López-Martínez et al., 1999b).

In Northern Europe, the Dutch-Belgian Limburg region has provided mainly hadrosaurids and theropods from the Maastricht Formation (Emael, Nekum and lower Meerssen members; see Mulder et al., 1997, 1998 for a review). The stratigraphically higher findings have been placed in the Belemnitella junior Biozone, assigned to the early Late Maastrichtian (Mulder et al., 1997; Smit et al., 1998); the top of this biozone, i.e., the base of the overlying $B$. casimirovensis Biozone, has been correlated with the base of the $A$. mayaroensis Biozone by Swinburne $(1990 ;$ c. $69 \mathrm{Ma})$ by means of ${ }^{87} \mathrm{Sr} /{ }^{86} \mathrm{Sr}$ isotopic ratios. Using this same method Vonhof \& Smit (1996) have, however, arrived at a different estimation for the base of this biozone, dated at approximately 150000 years 
before the end of the Cretaceous Period. Thus, either wrong dating or a highly diachronous boundary between Belemnitella junior and B. casimirovensis biozones (4 Ma; Christensen, 1996) has affected the calibration of the youngest dinosaur sites in Northern Europe.

In Central Europe, postcranial hadrosaurid remains have been found in marine deposits of the prealpine Helvetikum Zone in Bavaria (Wellnhofer, 1994). These deposits have been assigned to the Gansserina gansseri Biozone, suggesting a Late Campanianearly Late Maastrichtian age. Also near Sebastopol (Crimea, Ukraine), hadrosaurid limb bones have been found in deposits with the bivalve Aequipecten meridionalis, which have been attributed either to the uppermost Maastrichtian B. casimirovensis Biozone (Jeletzky, 1962) or to the Danian (see Brinkmann, 1988). Even if this last age determination cannot be trusted, the Crimean locality would be one of the youngest dinosaur sites in Europe, along with those in the south-central Pyrenees.

\section{The dinosaur extinction pattern in Europe}

A better understanding of the ages of dinosaur assemblages using new chronostratigraphic correlations, mainly those of the Pyrenees, allows the pattern of latest Cretaceous dinosaur succession and extinction in Europe to be approached more precisely. Previous studies, mainly supported by sites in southern France, have concluded that a faunal replacement of dinosaurs occurred in Europe during the Maastrichtian (Le Loeuff et al., 1994; Buffetaut \& Le Loeuff, 1997). Late Campanian-Early Maastrichtian dinosaurs would have consisted of dromeosaurid and abelisaurid theropods, titanosaurids, nodosaurids and the ornithopod Rhabdodon, while the Late Maastrichtian fauna would have consisted only of hadrosaurids and dromeosaurids (Buffetaut et al., 1997; Le Loeuff, 1998). Titanosaurids were supposed to have declined until they completely disappeared prior to the Late Maastrichtian, whereas hadrosaurids appeared in the Late Maastrichtian as a result of environmental changes linked to a major marine regression.

However, the recent discoveries in Spain together with updated age determinations suggest a different faunal succession. Theropod, titanosaur and hadrosaur dinosaurs show a continuous record from Late Campanian to latest Maastrichtian in Europe. During this long period, the coexistence of titanosaurid sauropods and hadrosaurs is well documented (Casanovas et al., 1987; Pereda Suberbiola \& Sanz, 1999; Canudo et al., 1999). The theropod Euronychodon is another element continuously present from Late Campanian to latest Maastrichtian (Antunes \& Sigogneau-Russell, 1991; Sigé et al., 1997; Csiki \& Grigorescu, 1998; this paper).

The main change during the latest Cretaceous dinosaur succession in Europe was the disappearance during the mid Late Maastrichtian of the euornithopod Rhabdodon and the nodosaurid ankylosaurs (Struthiosaurus), both of which are common in Upper Campanian and ?Lower Maastrichtian sites in Europe (Brinkmann, 1988; Pereda Suberbiola, 1992; Garcia et al., 1999). Their absence from Upper Maastrichtian deposits indicates that these dinosaurs were probably extinct before the mid Late Maastrichtian (contra Weishampel et al., 1991 and Pereda Suberbiola, 1992).

Dinosaur diversity in Europe during the Late Campanian and Maastrichtian was sustained by an increase in numbers of hadrosaurid and theropod taxa, compensating for the loss of the two groups that had become extinct. Therefore, the youngest European dinosaur faunas do not indicate a decreasing diversity.

With respect to the final extinction of all (nonavian) dinosaurs, some authors have suggested that European dinosaurs disappeared well before the Cretaceous/Tertiary boundary. Based on the last occurrence of in situ eggshells, Colombo (1996) and Galbrun (1997) have postulated that the extinction of European dinosaurs occurred at least 2 myr before the end of the Maastrichtian (Chron C30n or C31n). The discoveries in the Ager valley (López-Martínez et al., 1998, 1999b; Casanovas et al., 1999b) and at Arén indicate, however, that diverse and abundant dinosaurs were alive close to the end of the Cretaceous Period.

\section{Conclusions}

This paper documents the occurrence of rich and diverse dinosaur remains of Late Maastrichtian age in the south-central Pyrenees. The Arén sites have provided at least eight dinosaur species, among bones and eggshells: a hadrosaurid provisionally referred to as Euhadrosauria indet., a sauropod, and six distinct theropods (six prismatic eggshell types and teeth from a dromaeosaurine, a velociraptorine and a cf. Euronychodon). In addition, the Arén vertebrate assemblages include three crocodilians (the alligatorid Acynodon, an indeterminate alligatoroid and a 'trematochampsid'-like mesoeucrocodylian), a turtle (the bothremydid cf. Polysternon), squamates, amphibians and fish (lepisosteiformes, pycnodontiformes, teleosteans). Blasi 2 also contains a charophyte assemblage of four species: Amblyochara 
concava, Amblyochara sp. A, Peckichara sertulata, and a possible euryhaline marker, Feistiella sp. nov.

The dinosaur-bearing deposits at Arén have been correlated in a basinward direction with rocks belonging to the lower and middle part of the uppermost Maastrichtian Abathomphalus mayaroensis (planktonic foraminiferal) Biozone, thus not far below the Cretaceous/Tertiary boundary. This is the first report of dinosaur localities correlated with the Abathomphalus mayaroensis Biozone, and one of the rare cases of confident, high-resolution stratigraphic correlation between dinosaur sites and marine deposits. Other tentative Late Maastrichtian dinosaur localities in Europe are not well-constrained stratigraphically, or are older.

The composition of Arén assemblages does not support the idea of dinosaurian faunal replacement during the Late Maastrichtian. The main changes concern the extinction of the nodosaurid Struthiosaurus and the euornithopod Rhabdodon, well represented during the Late Campanian-?Early Maastrichtian. Minor changes are characterized by an increment of hadrosaurids and theropods and a probable decrease in sauropod numbers. Overall, diversity was sustained during the latest Cretaceous in Europe.

The rich dinosaur assemblages from Arén serve to refute previous assumptions of a gradual and diachronous extinction of the dinosaurs, suggesting instead a sudden demise close to the end of the Cretaceous in Europe. However, the decline of some dinosaur groups during the Maastrichtian is also supported by the data. Owing to the still-scattered nature of the fossil record of dinosaurs, more research will be necessary if the end-Cretaceous impact event is to be linked to the final extinction of the dinosaurs in the southern Pyrenees.

\section{Acknowledgements}

This work is the result of excavation projects carried out during 1997-1999 by a team from the Universities of Madrid (Complutense), Zaragoza and Basque Country, the Institute of Ilerdian Studies (IEI, Lleida) and GeoPlay Co. (Tremp). We acknowledge the help of Antoni Lacasa, Josep Pauls, Julio Pocino, Rubén Remacha (IEI, Lleida), José Expósito (Tremp), Paloma Sevilla (Universidad Complutense), César Laplana, Rafael Royo-Torres (Universidad de Zaragoza) and Iván Pérez during the field work. We thank J. Horner (Montana, USA) and D. B. Weishampel (Baltimore, USA) for kindly sharing their knowledge on hadrosaurs. Steven Robinson, David Horne, David Batten and an anonymous referee reviewed and improved earlier versions of the manuscript. The authorities and people of Arén gave us special support. Funds were provided by Consejería de Cultura, Diputación General de Aragón, and DGES Projects PB95-0398 and PB98-0813 (MEC, Spain).

\section{References}

Antunes, M. T. \& Sigogneau-Russell, D. 1991. Nouvelles données sur les dinosaures du Crétacé supérieur du Portugal. Comptes Rendus de l'Académie des Sciences, Paris, II 313, 113-119.

Ardèvol, L., Klimowitz, J., Malagón, J. \& Nagtegaal, P. J. C. 2000. Depositional sequence response to foreland deformation in the Upper Cretaceous of the Southern Pyrenees, Spain. Bulletin of the American Association of Petroleum Geologists 84, 566-587.

Bilotte, M. 1985. Le Crétacé supérieur des plates-formes est-pyrénéennes. Strata 5, 1-438.

Bilotte, M., Odin, G. S. \& Razin, P. 1999. Arguments à l'encontre des estimations d'âge biograduelles (et leur application en chronologie et stratigraphie séquentielle) dans le Sud-Ouest de la France. Bulletin de la Société Géologique de France 170, 465-473.

Bilotte, M., Tambareau, Y. \& Villatte, J. 1983. Le Crétacé supérieur et la limite Crétacé-Tertiaire en faciès continental dans le versant nord des Pyrénées. Géologie Méditerranéenne 10, 269-276.

Breton, G., Bilotte, M. \& Sigro, G. 1995. Dipsacaster jadeti sp. nov., Astropectinidae (Asteroidea, Echinodermata) du Maastrichtien des Petites Pyrénées (France). Bulletin de la Société Géologique de Normandie et Amis du Muséum du Havre 82, 35-42.

Brinkmann, W. 1984. Erster Nachweis eines Hadrosauriers (Ornithischia) aus dem unteren Garumnium (Maastrichtium) des Beckens von Tremp (provinz Lérida, Spanien). Paläontologische Zeitschrift 58, 295-305.

Brinkmann, W. 1988. Zur fundgeschichte und Systematik der Ornithopoden (Ornithischia, Reptilia) aus der Ober-kreide von Europe. Documenta Naturae 45, 1-157.

Broin, F. de 1977. Contribution à l'étude des chéloniens. Chéloniens continentaux du Crétacé et du Tertiaire de France. Mémoires de Muséum National d'Histoire Naturelle, Nouvelle Serié C 38, $366 \mathrm{pp}$.

Buffetaut, E. \& Cavin, L. 1995. Nouveaux restes de vertébrés du Maastrichtien supérieur de la carrière du Jadet (Saint-Martory, Haute-Garonne, France). Bulletin de la Société Géologique de Normandie et Amis du Muséum du Havre 82, 31-34.

Buffetaut, E. \& Le Loeuff, J. 1991. Late Cretaceous dinosaur faunas of Europe: some correlation problems. Cretaceous Research 12, 159-176.

Buffetaut, E. \& Le Loeuff, J. 1997. Late Cretaceous dinosaurs from the foothills of the Pyrenees. Geology Today, March-April, 60-68.

Buffettaut, E., Le Loeuff, J., Cavin, L., Duffaud, S., Gheerbrant, E., Laurent, Y., Martin, M., Rage, J. C., Tong, H. \& Vasse, D. 1997. Late Cretaceous non-marine vertebrates from Southern France: a review of recent finds. Geobios, Mémoire Spéciale 20 , 101-108.

Buscalioni, A. D., Ortega, F. \& Vasse, D. 1997. New crocodiles (Eusuchia: Alligatoroidea) from the Upper Cretaceous of southern Europe. Comptes Rendus de l'Académie des Sciences, Paris $325,525-530$.

Cande, S. C. \& Kent, D. V. 1995. Revised calibration of the geomagnetic polarity timescale for the Late Cretaceous and Cenozoic. Fournal of Geophysical Research 100 (B4), 6093-6095.

Canudo, J. I., Cuenca-Bescós, G., Ardèvol, L. \& López-Martínez, N. 1999. The youngest sauropod of Western Europe. Abstracts, IV European Workshop on Vertebrate Paleontology, Albarracín, pp. 30-31.

Casanovas, M. L., Pereda Suberbiola, X., Santafé, J. V. \& Weishampel, D. B. 1999a. A primitive euhadrosaurian dinosaur from the uppermost Cretaceous of the Ager syncline (southern Pyrenees, Catalonia). Geologie en Mijnbouw 78, 345-356. 
Casanovas, M. L., Pereda Suberbiola, X., Santafé, J. V. \& Weishampel, D. B. 1999b. First lambeosaurinae hadrosaurid from Europe: palaeobiogeographical implications. Geological Magazine 136, 205-211.

Casanovas, M. L., Santafé, J. V., Sanz, J. L. \& Buscalioni, A. D. 1987. Arcosaurios (Crocodilia, Dinosauria) del Cretácico superior de la Conca de Tremp (Lleida, Spain). Estudios Geológicos, Volumen Extraordinario Galve-Tremp, 95-110.

Caus, E., Gómez-Garrido, A. \& Rodes, D. 1988. Reevaluation of Lepidorbitoides evolution as a function of the age relations between species as established with nannoplankton biostratigraphy. Révue de Paléobiologie, Volume Spécial 2, 421-428.

Chiappe, L. M., Coria, R. A., Dingus, L., Jackson, F., Chinsamy, A. \& Fox, M. 1998. Sauropod dinosaur embryos from the Late Cretaceous of Patagonia. Nature 396, 258-261.

Christensen, W. K. 1996. A review of the Upper Campanian and Maastrichtian belemnite biostratigraphy of Europe. Cretaceous Research 17, 751-766.

Colombo, F. 1996. Stratigraphic and sedimentary characteristics of the Cretaceous-Tertiary boundary in the Ager Basin, Lleida Province, Spain. In Cretaceous-Tertiary mass extinctions. Biotic and environmental changes (eds McLeod, N. \& Keller, G.), pp. 399-413 (Norton, New York).

Company, J., Galobart, A. \& Gaete, R. 1998. First data on the hadrosaurid dinosaurs (Ornithischia, Dinosauria) from the Upper Cretaceous of Valencia, Spain. Oryctos 1, 121-126.

Csiki, Z. \& Grigorescu, D. 1998. Small theropods from the Late Cretaceous of the Hațeg Basin (western Romania) - an unexpected diversity at the top of the food chain. Oryctos 1, 87-104.

Currie, P. J., Rigby, J. K. \& Sloan, R. E. 1990. Theropod teeth from the Judith River Formation of southern Alberta, Canada. In Dinosaur systematics. Approaches and perspectives (eds Carpenter, K. \& Currie, P. J.), pp. 107-125 (Cambridge University Press, Cambridge).

Díaz-Molina, M. 1987. Sedimentación sintectónica asociada a una subida relativa del nivel del mar durante el Cretácico superior (Fm. Tremp, provincia de Lérida). Estudios Geológicos, Volumen Extraordinario Galve-Tremp, 69-93.

Eichenseer, H. 1988. Facies geology of Late Maastrichtian to Early Eocene coastal and shallow marine sediments (Tremp-Graus Basin, northeastern Spain). Arbeiten aus dem Institut und Museum für Geologie und Paläontologie, Universität Tubingen 1, 1-273.

Feist, M. \& Colombo, F. 1983. La limite Crétacé-Tertiaire dans le nord-est de l'Espagne du point de vue des charophytes. Géologie Méditerranéenne 10, 303-325.

Fondecave-Wallez, M. J., Souquet, P. \& Gourinard, Y. 1990. Sequence stratigraphy and grade-dating in the Senonian series from the South-Pyrenees (Spain), the sedimentary record of eustacy and tectonics. In Cretaceous resources, events and rhythms (eds Ginsburg, R. N. \& Beaudoin, B.), pp. 63-74 (Kluwer Academic Publishers, Dordrecht).

Galbrun, B. 1997. Did the European dinosaurs disappear before the K-T event? Magnetostratigraphic evidence. Earth and Planetary Science Letters 148, 569-579.

Galbrun, B., Feist, M., Colombo, F., Rocchia, R. \& Tambareau, Y. 1993. Magnetostratigraphy and biostratigraphy of CretaceousTertiary continental deposits, Ager Basin, province of Lerida, Spain. Palaeogeography, Palaeoclimatology, Palaeoecology 102, 41-52.

Galbrun, B., Ozawa, S., Samsó, J. M., Hottinger, L., Feist, M., Robin, E., Rocchia, R. \& Tambareau, Y. (in press). About the age of Laffiteina bibensis Marie in the Garumnian facies of the Campo section (central South Pyrenean Zone): biostratigraphical, magnetostratigraphical studies and iridium anomaly prospects. Dela Opera, Ljubljana.

Garcia, G., Pincemaille, M., Vianey-Liaud, M., Marandat, B., Lorenz, E., Cheylan, G., Cappetta, H., Michaux, J. \& Sudre, J. 1999. Découverte du premier squelette presque complet de Rhabdodon priscus (Dinosauria, Ornithopoda) du Maastrichtien inférieur de Provence. Comptes Rendus de l'Academie des Sciences, Paris 328, 415-421.
García Senz, J. et al. (in press). Memoria y mapa geológico 1:50,000, hoja 213 (Pont de Suert). Serie MAGNA, Instituto Tecnológico Geominero de España, Madrid.

Garrido Megías, A. \& Ríos Aragües, L. M. 1972. Síntesis geológica del Secundario y Terciario entre los ríos Cinca y Segre. Boletín Geológico y Minero España 83, 1-47.

Gheerbrant, E., Abrial, C. \& Cappetta, H. 1997. Nouveaux sites à microvertébrés continentaux du Crétacé terminal des Petites Pyrenées (Haute-Garonne et Ariège, France). Geobios, Mémoire Spéciale 20, 257-269.

Gilmore, C. W. 1924. On the skull and skeleton of Hypacrosaurus, a helmet-crested dinosaur from the Edmonton Cretaceous of Alberta. Canadian Geological Survey, Department of Mining, Contributions to Vertebrate Paleontology 38, 49-64, 86-89.

Gradstein, F. M., Agterberg, F. P., Ogg, J. G., Hardenbol, J., Van Veen, P., Thierry, J. \& Huang, Z. 1995. A Triassic, Jurassic and Cretaceous time scale. In Geochronology, time scales and global stratigraphic correlation (eds Berggren, W. A., Kent, D. V., Aubry, M. P. \& Hardenbol, J.), SEPM (Society for Sedimentary Geology), Special Publication 54, 95-126.

Grambast, L. 1971. Remarques phylogénétiques et biochronologiques sur les Septorella du Crétacé terminal de Provence et les Charophytes associées. Paléobiologie Continentale 2, $38 \mathrm{pp}$.

Grigorescu, D. 1983. A stratigraphic, taphonomic and paleoecologic approach to a "forgotten land": the dinosaur-bearing deposits from the Hațeg Basin (Transylvania-Romania). Acta Palaeontologica Polonica 28, 103-121.

Grigorescu, D. 1992. Nonmarine Cretaceous formations of Romania. In Aspects of nonmarine Cretaceous geology (eds Mateer, N. J. \& Chen Peiji), pp. 142-164 (China Ocean Press, Beijing).

Grigorescu, D., Weishampel, D., Norman, D., Seclamen, M., Rusu, M., Baltres, A. \& Teodorescu, V. 1994. Late Maastrichtian dinosaur eggs from the Haţeg Basin (Romania). In Dinosaur eggs and babies (eds Carpenter, K., Hirsch, K. F. \& Horner, J. R.), pp. 75-87 (Cambridge University Press, Cambridge)

Haq, B. U., Hardenbol, J. \& Vail, P. R. 1987. Chronology of fluctuating sea levels since the Triassic. Science 235, $1156-1167$.

Head, J. J. 1998. A new species of basal hadrosaurid (Dinosauria, Ornithischia) from the Cenomanian of Texas. Fournal of Vertebrate Paleontology 18, 718-738.

Horner, J. R. 1988. A new hadrosaur (Reptilia, Ornithischia) from the Upper Cretaceous Judith River Formation of Montana. Fournal of Vertebrate Paleontology 8, 314-321.

Horner, J. R. 1990. Evidence of diphyletic origination of hadrosaurian (Reptilia, Ornithischia) dinosaurs. In Dinosaur systematics: perspectives and approaches (eds Carpenter, K. \& Currie, P. J.), pp. 179-187 (Cambridge University Press, Cambridge).

Jeletzky, J. A. 1962. The allegedly Danian dinosaur-bearing rocks of the globe and the problem of the Mesozoic-Cenozoic boundary. fournal of Paleontology 36, 1005-1018.

Krauss, S. 1990. Stratigraphy and facies of the "Garumnian" - Late Cretaceous to Early Paleogene - in the Tremp region, central Southern Pyrenees. Tübinger Geowissenschaftliche Arbeiten 11, $1-152$.

Lapparent, F. de \& Murelaga, X. 1996. Une nouvelle faune de chéloniens dans le Crétacé supérieur européen. Comptes Rendus de l'Académie des Sciences, Paris, IIa 323, 729-735.

Laurent, Y., Le Loeuff, J. \& Buffetaut, E. 1997. Les Hadrosauridae (Dinosauria, Ornithopoda) du Maastrichtien supérieur des Corbières orientales (Aude, France). Révue de Paléobiologie 16, 411-423.

Laurent, Y., Cavin, L. \& Bilotte, M. 1999. Découverte d'un gisement à vertébrés dans le Maastrichtien supérieur des Petites-Pyrenées. Comptes Rendus de l'Académie des Sciences, Paris 328, 781.

Le Loeuff, J. 1998. Les dinosaures du Crétacé supérieur de l'île ibéro-armoricaine. In First International Meeting on Dinosaur Paleobiology, pp. 49-64 (Museu Nacional de História Natural, Lisboa). 
Le Loeuff, J., Buffetaut, E. \& Martin, M. 1994. The last stages of dinosaur faunal history in Europe: a succession of Maastrichtian dinosaur assemblages from the Corbières (southern France). Geological Magazine 131, 625-630.

Lepicard, B. 1985. Le Crétacé terminal et le Paléocène basal dans les Petites Pyrenees et les dômes annexes. Thèse, Université Paul Sabatier; Strata (Toulouse) 4, 1-276.

Lepicard, B., Bilotte, M., Massieux, M., Tambareau, Y. \& Villatte, J. 1985. Faunes et flores au passage Crétacé-Tertiaire en faciès continental dans les Petites Pyrénées. Geobios 18, 707-800.

Liebau, A. 1973. El Maastrichtiense lagunar "Garumniense" de Isona. Libro-Guía, XIII Coloquio Europeo Micropaleontología, pp. 87-112 (ENADIMSA, Madrid).

López-Martínez, N., Ardèvol, L., Arribas, M. E., Civis, J. \& González-Delgado, A. 1998. The geological record in nonmarine environments around the $\mathrm{K} / \mathrm{T}$ boundary (Tremp Formation, Spain). Bulletin de la Société Géologique de France 169, $11-20$.

López-Martínez, N., Canudo, J. I. \& Cuenca, G. 1999a. Latest Cretaceous eggshells from Arén (Southern Pyrenees, Spain). Abstracts, First International Symposium on Dinosaur Eggs and Babies, Isona (Lleida), pp. 35-36.

López-Martínez, N., Fernández-Marrón, M. T. \& Valle, M. F. 1999b. The succession of vertebrates and plants across the Cretaceous-Tertiary boundary in the Tremp Formation, Ager valley (south-central Pyrenees, Spain). Geobios 32, 617-627.

López-Olmedo, F. \& Ardèvol, L. (in press). Mapa Geológico de España, scale 1:50,000, Sheet no. 251 (Arén), Second Series. Instituto Tecnológico y GeoMinero de España, Madrid.

Masriera, A. \& Ullastre, J. 1988. Nuevos datos sobre las capas maestrichtienses con Septorella: su presencia al norte del Montsec (Pirineo catalán). Acta Geológica Hispánica 23, 71-77.

Massieux, M., Tambareau, Y. \& Villatte, J. 1979. Découverte de Septorella brachycera et de S. ultima Grambast (Charophytes, Clavatoracées) dans le Maastrichtien supérieur des Petites Pyrenées. Conséquences stratigraphiques. Geobios 12, 899-905.

Massieux, M., Tambareau, Y. \& Villatte, J. 1989. Nouveaux gisements à Charophytes du Dano-Montien nord-pyrénéen. Revue de Micropaléontologie 32, 140-150.

Médus, J., Colombo, F. \& Durand, J. P. 1992. Pollen and spore assemblages of uppermost Cretaceous continental formations of south-eastern France and north-eastern Spain. Cretaceous Research 13, 119-132.

Méon, H. 1991. Études sporopolliniques à la limite CrétacéTertiaire: la coupe du Kef (Tunisie Nord-Occidentale); étude systématique, stratigraphie, paléogéographie et évolution climatique. Palaeontographica Abteilung B 223, 107-168.

Mulder, E. W. A., Kuypers, M. M. M., Jagt, J. W. M. \& Peeters, H. H. G. 1997. A new late Maastrichtian hadrosaurid record from northeast Belgium. Neues fahrbuch für Geologie und Paläontologie, Monatshefte 1997, 339-347.

Mulder, E. W. A., Jagt, J. W. M., Kuypers, M. M. M., Peeters, H. H. G. \& Rompen, P. 1998. Preliminary observations on the stratigraphic distribution of Late Cretaceous marine and terrestrial reptiles from the Maastrichtian type area (SE Netherlands, NE Belgium). Oryctos 1, 55-64.

Murelaga, X., Pereda Suberbiola, X., Astibia, H. \& Lapparent, F. de 1998. Primeros datos sobre los quelonios del Cretácico superior de Lleida. Geogaceta 24, 239-242.

Nagtegaal, P. J. C., Van Vliet, A. \& Brouwer, J. 1983. Syntectonic coastal offlap and concurrent turbidite deposition: the Upper Cretaceous Aren Sandstone in the south-central Pyrenees, Spain. Sedimentary Geology 34, 185-218.

Paris, J.-P. \& Taquet, P. 1973. Découverte d'un fragment de dentaire d'Hadrosaurien (Reptile, Dinosaurien) dans le Crétacé supérieur des Petites-Pyrénées (Haute-Garonne). Bulletin du Muséum National d'Histoire Naturelle 130, 17-27.

Peláez-Campomanes, P., López-Martínez, N., Álvarez-Sierra, M. A. \& Daams, R. 2000. The earliest mammal of the European Paleocene: the multituberculate Hainina. Fournal of Paleontology 74, 701-711.
Pereda Suberbiola, J. 1992. A revised census of European Late Cretaceous nodosaurids (Ornithischia: Ankylosauria): last occurrence and possible extinction scenarios. Terra Nova 4, 641-648.

Pereda Suberbiola, X. \& Sanz, J. L. 1999. The ornithopod dinosaur Rhabdodon from the Upper Cretaceous of Laño (Iberian Peninsula). Estudios del Museo de Ciencias Naturales de Alava 14 (Número Especial), 257-272.

Pujalte, V., Baceta, J. I., Dinarès-Turell, J., Orue-Etxebarria, X., Parés, J.-M. \& Payros, A. 1995. Biostratigraphic and magnetostratigraphic intercalibration of the latest Cretaceous and Paleocene depositional sequences from the deep-water Basque Basin, western Pyrenees, Spain. Earth and Planetary Science Letters 136, 17-30.

Rauhut, O. W. M. \& Werner, C. 1995. First record of the family Dromeosauridae (Dinosauria: Theropoda) in the Cretaceous of Gondwana (Wadi Milk Formation, northern Sudan). Paläontologische Zeitschrift 69, 475-489.

Riveline, J., Berger, J. P., Feist, M., Martin-Closas, C., Schudack, M. \& Soulié-Märsche, I. 1996. European Mesozoic-Cenozoic charophyte biozonation. Bulletin de la Société Géologique de France 167, 453-468.

Robaszynski, F. \& Caron, M. 1995. Foraminifères planctoniques du Crétacé: commentaire de la zonation Europe-Méditerranée. Bulletin de la Société Géologique de France 166, 681-692.

Schudack, M. 1986. Zur Nomenklatur der Gattungen Porochara Mädler 1955 (syn. Musacchiella Feist \& Grambast-Fessard 1984) und Feistiella n. gen. (Charophyta). Paläontologische Zeitschrift 60, 21-27.

Schudack, M., Turner, C. \& Peterson, F. 1998. Biostratigraphy, paleoecology and biogeography of charophytes and ostracods from the Upper Jurassic Morrison Formation, Western Interior, USA. Modern Geology 22, 379-414

Sigé, B., Buscalioni, A. D., Duffaud, S., Gayet, M., Orth, B., Rage, J.-C. \& Sanz, J. L. 1997. Etat des données sur le gisement crétacé supérieur continental de Champ-Garimond (Gard, Sud de la France). Münchener Geowissenchaften Abhandlungen A 34, 111-130.

Smit, J., Jagt, J. W. M., Dortagns, R. W. \& Severijns, J. 1998. Field excursion: ENCI Maastricht BV quarry (Maastricht) and Geulhemmerberg K/T boundary section (Geulhem, Berg en Terblijt). In Third European Workshop on Vertebrate Palaeontology (eds Jagt, J. W. M., Lambers, P. H., Mulder, E. W. A. \& Schulp, A. S.), 26 pp. (Natuurhistorisch Museum Maastricht).

Swinburne, N. H. M. 1990. The extinction of the rudist bivalves. $\mathrm{PhD}$ thesis, Open University, Milton Keynes, $175 \mathrm{pp}$.

Tambareau, Y., Hottinger, L., Rodríguez Lázaro, J., Villatte, J., Babinot, J.-F., Colin, J.-P., García Zarraga, E., Rocchia, R. \& Guerrero, N. 1997. Communautés fossiles benthiques aux alentours de la limite Crétacé-Tertiaire dans les Pyrénées. Bulletin de la Société Géologique de France 168, 795-804.

Varricchio, D. J., Jackson, F., Borkowski, J. J. \& Horner, J. R. 1997. Nest and egg clutches of the dinosaur Troodon formosus and the evolution of avian reproductive traits. Nature 385, 247-250.

Vianey-Liaud, M., Hirsch, K., Sahni, A. \& Sigé, B. 1997. Late Cretaceous Peruvian eggshells and their relationships with Laurasian and eastern Godwanian material. Geobios 30, 75-90.

Vianey-Liaud, M. \& López-Martínez, N. 1997. Late Cretaceous dinosaur eggshells from the Tremp Basin (Southern Pyrenees, Lleida, Spain). Fournal of Paleontology 71, 1157-1171.

Vonhof, H. B. \& Smit, J. 1996. Strontium-isotope stratigraphy of the type Maastrichtian and the Cretaceous/Tertiary boundary in the Maastricht area (SE Netherlands). Geologie en Mijnbouw $\mathbf{7 5}$ 275-282.

Weishampel, D. B. \& Horner, J. R. 1990. Hadrosauridae. In The Dinosauria (eds Weishampel, D. B., Dodson, P. \& Osmólska, H.), pp. 534-561 (University of California Press, Berkeley).

Weishampel, D. B., Grigorescu, D. \& Norman, D. B. 1991. The dinosaurs of Transylvania: island biogeography in the Late Cretaceous. National Geographic Research and Exploration 7, 196-215. 
Weishampel, D. B., Norman, D. B. \& Grigorescu, D. 1993. Telmatosaurus transylvanicus from the Late Cretaceous of Romania: the most basal hadrosaurid dinosaur. Palaeontology 36, 361-385.

Wellnhofer, P. 1994. Ein Dinosaurier (Hadrosauridae) aus der Oberkreide (Maastricht, Helveticum-Zone) des bayerischen
Alpenvorlandes. Mitteilungen der Bayerischen Staatssammlung für Paläontologie und Historische Geologie 34, 221-238.

Westphal, M. \& Durand, J. P. 1990. Magnétostratigraphie des séries continentales fluvio-lacustres du Crétacé supérieur dans le synclinal de l'Arc (région d'Aix-en-Provence). Bulletin de la Société Géologique de France 6, 609-620. 